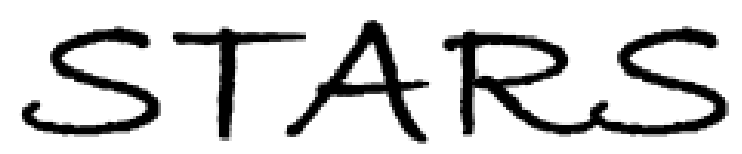

University of Central Florida

STARS

Retrospective Theses and Dissertations

Winter 1980

\title{
Benthic Macroinvertebrates in a Hydrilla Infested Central Florida Lake
}

Stefani L. Scott

University of Central Florida

Part of the Biology Commons

Find similar works at: https://stars.library.ucf.edu/rtd

University of Central Florida Libraries http://library.ucf.edu

This Masters Thesis (Open Access) is brought to you for free and open access by STARS. It has been accepted for inclusion in Retrospective Theses and Dissertations by an authorized administrator of STARS. For more information, please contact STARS@ucf.edu.

\section{STARS Citation}

Scott, Stefani L., "Benthic Macroinvertebrates in a Hydrilla Infested Central Florida Lake" (1980).

Retrospective Theses and Dissertations. 515.

https://stars.library.ucf.edu/rtd/515

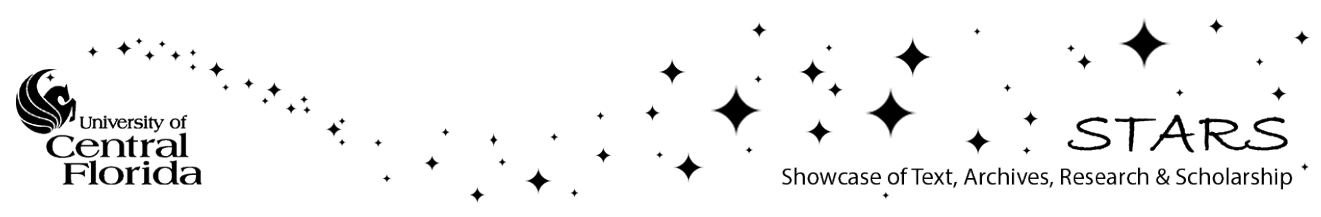




\title{
BENTHIC MACROINVERTEBRATES IN A HYDRILIA INFESTED CENTRAI FLORIDA LAKE
}

\author{
BY \\ STEFANI I. SCOTT \\ B.A., Wesleyan College, 1974
}

\section{THESIS}

Submitted in partial fulfillment of the requirements for the degree of Master of Science: Biology in the Graduate Studies Program of the College of Natural Sciences at the University of Central Florida; Orlando, Florida

Winter Quarter

1980 


\section{ABSTRACT}

Benthic macroinvertebrates and physicochemical parameters were monitored simultaneously with hydrilla in a central Florida lake. Changes in the benthos were described in relation to plant growth. Twenty-seven of the 54 taxa of benthic macroinvertebrates collected were members of the Family Chironomidae. Chironomids and oligochaetes numerically dominated the benthos, comprising $82 \%$ of the individuals collected. The greatest numbers of species and individuals were found during the winter when hydrilla biomass was low. Hydrilla biomass ranged from $0.382 \mathrm{~kg} / \mathrm{m}^{2}$ in April, 1977 to $2.275 \mathrm{~kg} / \mathrm{m}^{2}$ in October, 1977. Low numbers of species and individuals were collected from bottom sediments during summer and fall. Dissolved oxygen concentrations at the bottom were approximately $2.0 \mathrm{ppm}$ during summer and fall and possibly limited benthic organisms. The annual means for the Shannon and Simpson Indices for the benthos were 1.92 and 0.36 , respectively. 


\section{ACKNOWLEDGMENTS}

I am grateful to Dr. John A. Osborne for providing research opportunities and guidance. I am most thankful to Mr. Donald Schmitz for his invaluable assistance and his partnership when sampling. I gratefully acknowledge $\mathbb{M r}$. Jerrel Daigel for his instruction in benthos identification. I thank Drs. Franklin F. Snelson, Jr. and Roseann S. White for their guidance and their review of the manuscript. Finally, I am indebted to Dr. I. Jack Stout for his counseling and encouragement. I express my deepest appreciation to my husband, Patrick Killian, for his love and patience. 


\section{TABLE OF CONTENTS}

List of Tables-_-

List of Figures-_- vi Introduction-_. 1

Methods and Materials--_- 3

Results and Discussion-_-_-_-_ 9

Summary-- 28

Appendix I. Monthly means of physicochemical and chlorophyll parameters in Little Lake Barton, January to December, 1977. -------30

Appendix II. Classification of benthic macroinvertebrates collected in Little Lake Barton from January to December, 1977...-.-5?

Literature Cited-_-_- 60 


\section{LIST OF TABLES}

Table

Page

1. Monthly and annual mean values for physicochemical and chlorophyll parameters in Little Lake Barton from January to December, 1977.

2. Monthly and annual mean numbers

(organisms $/ \mathrm{m}^{2}$ ) of benthic macroinvertebrates collected in Little Lake Barton from

January to December, 1977. 


\section{LIST OF FIGURES}

Figure

Page

1. Bathymetric map of Little Lake Barton -..-. 4

2. Monthly mean hydrilla biomass and $95 \%$ confidence limits in Little Lake Barton from February to December, 1977.

3. Monthly mean numbers of organisms and species of benthic macroinvertebrates collected in Little Lake Barton from January to December, 1977.

4. Monthly means ( $\pm 95 \%$ confidence limits) of the Shannon Index for benthic macroinvertebrates in Little Lake Barton, January to

December, 1977.

5. Monthly means ( $\pm 95 \%$ confidence limits) of the Simpson Index for benthic macroinvertebrates in Little Lake Barton, January to

December, 1977. 


\section{INTRODUCTION}

Benthic macroinvertebrates function on several trophic levels in freshwater ecosystems. As herbivores and carnivores, they feed on living tissues of vascular plants, algae and other invertebrates (Cummins, 1973; Brinkhurst, 1974). Benthic macroinvertebrates serve as a primary food source for many fish (Ball and Hayne, 1952; Gerking, 1962). As detritivores, they are involved in recycling of organic matter (Brinkhurst and Jamieson, 1971).

Benthic macroinvertebrates have various requirements for growth and reproduction. Their distribution in freshwater is affected by such factors as water quality, type of bottom sediment and diversity and abundance of plants (Wetzel, 1975). For example, it has been observed that more species of benthic macroinvertebrates are in littoral zones of lakes than in profundal zones (Rosine, 1955; Cole and Underhill, 1965; Jonasson, 1969). Due to the presence of plants, the littoral zone is a more diverse habitat than the bottom sediment of the profundal zone. Numerous investigators have reported that the abundance and diversity of macroinvertebrates is dependent on the species, distribution and abundance of aquatic macrophytes (Macan, 1961; Petre, 1968; McLachlan, 1969, 1975). In a detailed 
analysis of nutrient rich experimental ponds, Hall, et al. (1970) reported that the benthic community shifted from large bottom dwellers to small mobile browsers when Elodea. canadensis and Potamogeton sp. replaced Chara.

Hydrilla verticillata Royle, an exotic submerged aquatic macrophyte, was introduced into South Florida in the early 1960's. By 1967, it was found throughout Florida and has now spread into Georgia, Alabama, Louisiana, Texas, Mississippi, California and Iowa (Blackburn, et al., 1969; Haller, 1976). In early spring hydrilla grows rapidly from apical meristem fragments, roots, tubers or turions. By efficiently utilizing carbon dioxide and light it spreads throughout the water column forming dense surface mats by late summer (Haller, 1976; Bowes, et al., 1977). Extensive growths of hydrilla may alter the dynamics of a lake by contributing significantly to factors such as oxygen, $\mathrm{pH}$, alkalinity, food supply, habitat and nutrients (Steward, 1970; Steward and Elliston, 1974; Haller and Sutton, 1975; Bowes, et al., 1977). These factors relate directly to the diversity and abundance of benthic macroinvertebrates. The objective of this study was to describe the diversity and abundance of benthic macroinvertebrates as related to the growth of hydrilla in a central Florida lake. 


\section{METHODS AND MATERIALS}

Little Lake Barton, a solution basin located in Orlando, Florida (latitude: $28^{\circ} 36^{\prime} \mathrm{N}$; longitude: $81^{\circ} 22^{\prime} \mathrm{W}$ ), has a surface area of 5.42 ha and a mean depth of $1.63 \mathrm{~m}$ (Figure 1). The lake is nearly circular with a shoreline development of 1.04 and volume development of 0.77 . Bottom sediment is composed of sand overlaid by sapropel. Runoff into the lake is from surrounding lawns, roadways and commercial areas; the soil of the drainage area consists of excessively to moderately drained fine sands (Leighty, 1960).

Hydrilla has infested Little Lake Barton for approximately seven years. During the study it dominated the littoral and profundal zones of the lake. Little Lake Barton was stocked with grass carp by the Florida Department of Natural Resources in October, 1976 (32 fish/ha) and in October, 1977 (15 fish/ha) for hydrilla control. From October, 1976 to October, 1978 hydrilla biomass decreased $45 \%$ due to feeding of grass carp (Osborne and Sassic, 1979). Other less abundant littoral plants in Little Lake Barton were Typha latifolia I., Sagittaria latifolia Willd., Pontederia lanceolata I., Nuphar Iuteum (I.), and Eichhornia crassipes (Mart.) Solms. 
Figure 1. Bathymetric map of Little Lake Barton. 

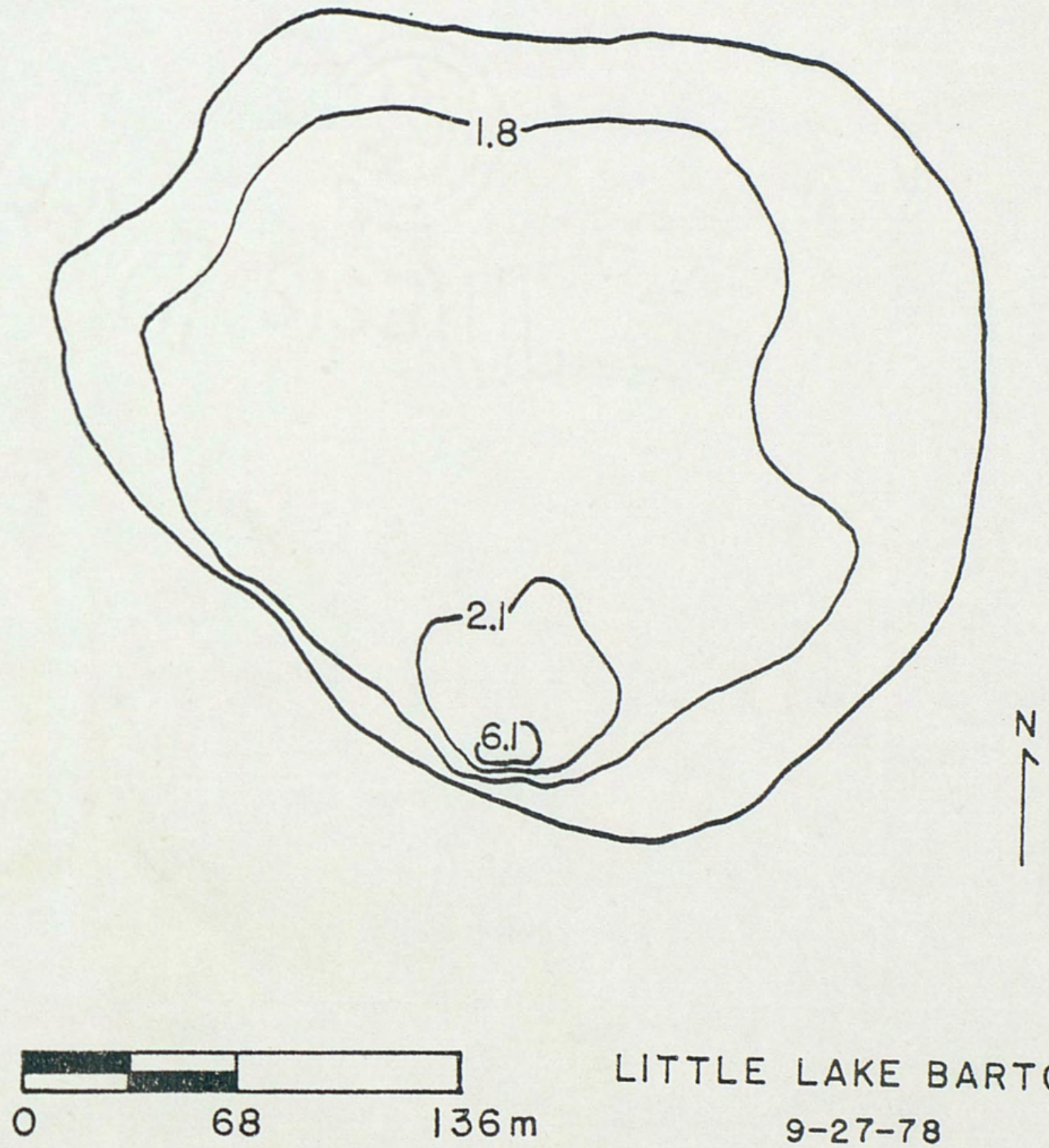
LITTLE LAKE BARTON $9-27-78$


Physicochemical measurements were taken monthly from January to December, 1977 at six random stations. Water samples were collected with a 1.2 I Kemmerer water sampler at $1.0 \mathrm{~m}$ below the surface.

Water temperature was measured at $0.5 \mathrm{~m}$ intervals in the water column with a YSI ModeI 44 telethermometer. Visible light penetration was determined with a standard black and white $20 \mathrm{~cm}$ Secchi disc. Color and turbidity were measured spectrophotometrically using a Beckman Model 26 spectrophotometer with the procedures outlined in Environmental Protection Agency (1974) and American Public Health Association (1971). Depth was measured at each station with a weighted line.

Hydrogen-ion concentration was determined with a Sargent-Welch pH meter; carbonate, bicarbonate and total alkalinity were determined by titration (American Public Health Association, 1971). Inorganic carbon was calculated by using alkalinity and pH data (Bachmann, 1959). Specific conductivity was taken with a YSI Model 33 specific conductivity meter.

Dissolved oxygen concentrations were determined with a YSI BOD probe and meter at $1.0 \mathrm{~m}$ below the surface and at the bottom; the meter was calibrated with the modified azide Winkler method (American Public Health Association, 1971). Orthophosphate concentrations were measured spectrophotometrically with the ascorbic acid-ammonium 
molybdate method (American Public Health Association, 1971). Nitrate nitrogen was determined using the brucine method (Environmental Protection Agency, 1974). Nitrite nitrogen was determined by procedures outlined in Standard Methods for the Examination of Water and Wastewater (American Public Health Association, 1971).

Algae was filtered from water samples onto glass fiber filters (pore size $=0.45 \mathrm{m \mu}$ ). Chlorophyll pigment was extracted from the filters in $10 \mathrm{ml}$ of acetone for $48 \mathrm{hr}$ at 4 C. Chlorophyll concentrations were calculated by the equation of Richards with Thompson (1959).

Hydrilla was collected bimonthly at twenty random stations from February to December, 1977. A submersed aquatic plant sampler was used to obtain samples (Osborne and Sassic, 1979). Samples were washed in nylon bags and spun at $540 \mathrm{rpm}$ for 4 minutes in a garment washer to remove excess water. Fresh weight biomass $\left(\mathrm{kg} / \mathrm{m}^{2}\right)$ was determined to the nearest $0.001 \mathrm{~kg}$.

Benthic macroinvertebrates were collected monthly at six random stations with a $0.0225 \mathrm{~m}^{2}$ tall-form Ekman grab. Two samples per station were pooled and washed through a \#30 mesh sieve. Organisms were hand-picked live from washed samples under light and magnification using a dilution technique and preserved in 90-5-5\% solution of ethyl alcohol, formalin and water. Chironomidae larvae were permanentiy mounted on glass slides for identification 
(Beck, 1976). Identification was accomplished with Bermer (1950), Pennak (1953), Needham and Westfall (1955), Ward and Whipple (1959), Beck and Beck (1966, 1969), Parrish (1968), Usinger (1968), Mason (1968) and Beck (1976). The Shannon Index for species diversity $(\bar{d})$ and the Simpson Index for dominance (SI) were used to determine changes in benthic community structure. Enumeration data per species were used to calculate the indices as follows: $\bar{d}=-\Sigma\left(n_{i} / N\right)$ $\log _{2}\left(n_{i} / N\right)$ and $S I=\sum n_{i}\left(n_{i}-1\right) / N(N-1)$ where $n_{i}$ equals the number of individuals of the ith species and $N$ equals the number of individuals of all species (Simpson, 1949; Wilhm and Dorris, 1968). 


\section{RESULTS AND DISCUSSION}

\section{Description of the Environment}

Hydrilla biomass declined in winter and was lowest in April, $1977\left(0.382 \mathrm{~kg} / \mathrm{m}^{2}\right)$ (Figure 2). The decline of hydrilla in winter was probably due to cooler water temperatures, a decrease in solar radiation and grazing by grass carp. Water temperatures were lowest in January and February, 1977 (Table 1). As the water warmed in the spring, hydrilla biomass increased exponentially to a seasonal maximum in October, $1977\left(2.275 \mathrm{~kg} / \mathrm{m}^{2}\right.$ ) (Figure 2). Water temperatures were relatively uniform from surface to bottom in Little Lake Barton during summer and fall; hydrilla formed dense surface mats during these seasons (Table 1). Monthly mean water temperature was highest in June, 1977 ( $30.9 \mathrm{C}$ at the surface and $30.0 \mathrm{C}$ at the bottom). Light penetrated to the bottom in Little Lake Barton during summer and in areas where matting of hydrilla did not occur (Table 1). From June to November, 1977, light transmission was greatest, and turbidity and color were low (Table 1). By absorbing nutrients usually available for phytoplankton and by reducing water circulation, the summer growth of hydrilla probably aids in decreasing turbidity. During winter when hydrilla biomass was low, turbidity and color were high (Table 1). Turbidity was highest in April, 
Figure 2. Monthly mean hydrilla biomass and $95 \%$ confidence limits in Little Lake Barton from February to December, 1977. 


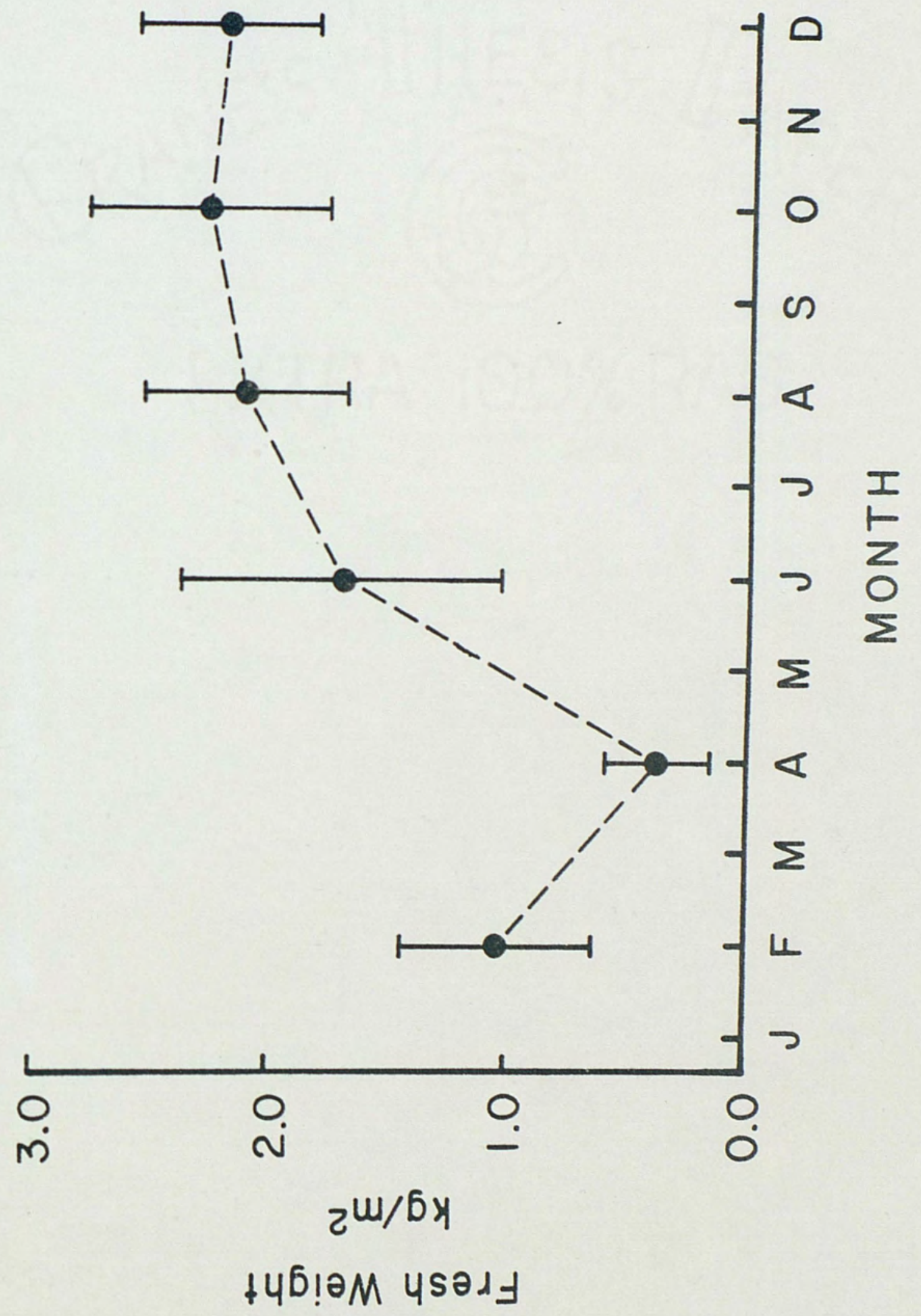


Table 1. Monthly and annual mean values for physicochemical and chlorophyll parameters in Little Lake Barton from January to December, 1977.

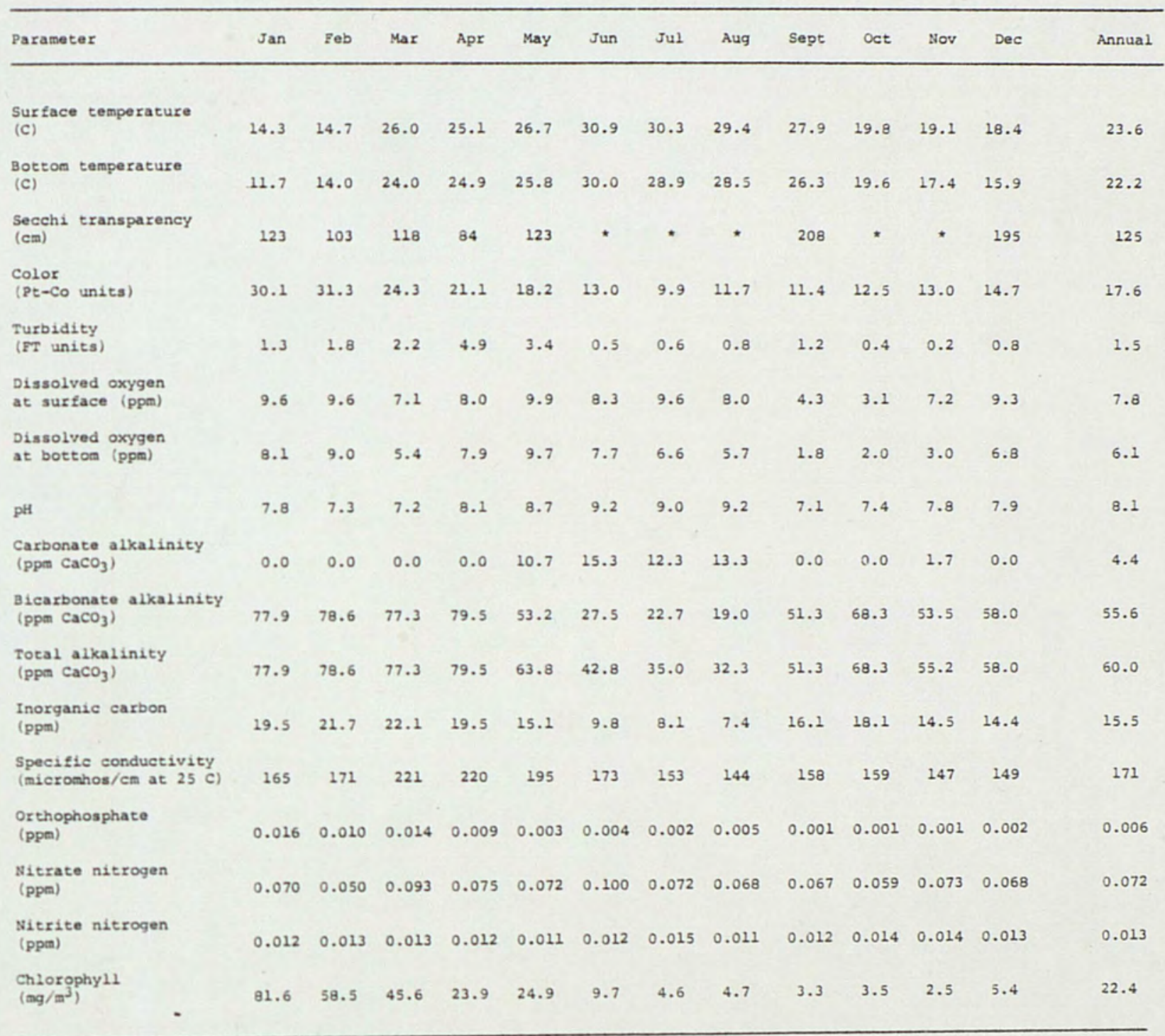

- Sechi disc was visible on the lake bottom. 
1977 (4.9 FT units), while color was highest in February, 1977 (31.1 Pt-Co units) (Appendix I, Figures 6 and 7). The annual mean color value for Little Lake Barton was 17.6 Pt-Co units. This value was similar to those reported by Shannon and Brezonik (1972) and Nordlie (1976) for clear alkaline central Florida lakes. Very clear lakes yield color values that approach 0.0 Pt-Co units (Wetzel, 1975).

Chlorophyll concentrations were high in winter when hydrilla biomass was low and decreased with growth of hydrilla. Chlorophyll concentrations remained low through summer and fall (Appendix I, Figure 8). Dense stands of submerged macrophytes inhibit the growth of phytoplankton by successfully competing for light and nutrients (Hasler and Jones, 1949; Stangeberg, 1968; Goulder, 1969).

Total alkalinity and inorganic carbon decreased while $\mathrm{pH}$ increased in Little Lake Barton during the summer growing season (Appendix I, Figures 9, 10 and 11). Alkalinity in Little Lake Barton was primarily due to the presence of bicarbonate ions (Table 1). Carbonate alkalinity was present only from May to August and in November, 1977 (Table 1). Bicarbonate alkalinity was lowest in summer (Appendix I, Figure 12). The decrease in bicarbonate alkalinity during the height of the growing season was probably due to the utilization of bicarbonate ions for photosynthesis by hydrilla. Many submerged angiosperms and macroalgae have the ability to assimilate 
bicarbonate ions (Raven, 1970). Steward and Elliston (1974) found that sodium bicarbonate caused an enhancement of hydrilla growth. A sharp rise in total alkalinity and inorganic carbon occurred between September and October, 1977, at a time when hydrilla biomass was highest (Appendix I, Figures 9 and 10). This abrupt change in the bicarbonate alkalinity may have been caused by respiration of hydrilla. In hard water environments specific conductivity varies proportionally with bicarbonate and carbonate alkalinity (Otsuki and Wetzel, 1974). Seasonal variations in specific conductivity in Little Lake Barton patterned changes in alkalinity (Appendix I, Figure 13). Specific conductivity was highest in April, 1977 (220 micromhos/cm at 25 C) as was alkalinity. During summer and fall specific conductivity was lowest (Table 1). Orthophosphate, nitrate and nitrite nitrogen concentrations were relatively low during the study (Table 1). The annual mean concentration for orthophosphate was 0.006 ppm; nitrate nitrogen was $0.072 \mathrm{ppm}$ and nitrite nitrogen was $0.013 \mathrm{ppm}$. Orthophosphate concentrations peaked in winter when hydrilla biomass was low but decreased with growth of hydrilla in the late spring and summer (Appendix I, Figure 14). Tissue contents of phosphorus in hydrilla have been reported to be directly related to solution levels of the mineral (Steward and Elliston, 1974). Although differences in nitrate and nitrite nitrogen 
concentrations were observed between months, seasonal patterns were not evident in Little Lake Barton (Appendix I, Figures 15 and 16 ).

Accelerated photorespiration in the water column caused by dense mats of vegetation may cause a depletion of dissolved oxygen in littoral zones of lakes (Penfound, 1956; Busemi, 1958; Hough, 1974). Dense mats of hydrilla reduced water circulation and light penetration in Little Lake Barton during summer and fall, and influenced dissolved oxygen concentrations. Dissolved oxygen concentrations at the bottom were at or below $2.0 \mathrm{ppm}$ (approximately $20 \%$ saturation) in September and October, 1977 (Table 1). Dissolved oxygen may have been limiting to benthic organisms during summer and fall. Concentrations between 1.0 and $2.0 \mathrm{ppm}$ dissolved oxygen (10-15\% saturation) are lethal to a majority of benthic macroinvertebrates (Wetzel, 1975). In winter and spring when hydrilla biomass was low dissolved oxygen concentrations were highest (Appendix I, Figures 17 and 18). Benthic Macroinvertebrates

A total of 54 taxa of benthic macroinvertebrates was collected from Little Lake Barton during the study (Table 2). Classification of the benthos is given in Appendix II. Twenty-seven of the 54 taxa were members of the Chironomidae. Chironomids and oligochaetes numerically dominated the benthos; Chironomids comprised $60 \%$ of the 
organisms while oligochaetes accounted for $22 \%$. Generally, chironomids and oligochaetes dominate the benthic community of eutrophic lakes (Pennak, 1953; Gaufin and Tarzwell, 1955; Beck, 1969; Brinkhurst and Jamieson, 1971). The most abundant species in Little Lake Barton were Chironomus stigmaterus, Nais sp., Limnodrilus hoffmeisteri, Chaoborus punctipennis, Dicrotendipes sp., Nimbocera sp. and an unidentified species of Hydracarina (Table 2). Turbificid worms, particularly Limnodrilus hoffmeisteri, are common in lakes which are organically polluted. Members of Hydracarina are most abundant in lakes with rooted vegetation such as Little Lake Barton (Pennak, 1953). The chironomids and Chaoborus punctipennis are adapted to low oxygenated waters and are common in eutrophic lakes in Florida (Provost, 1958; Beeton, 1965; Beck and Beck, 1969; Cowell, et al., 1975).

The greatest number of individuals and species of benthic macroinvertebrates occurred during winter in Little Lake Barton (Figure 3). The numbers of individuals as well as numbers of species declined in early spring and remained low until late fall. Peak numbers in February, 1977 were caused primarily by an increase in Chironomidae larvae $\left(6881 / \mathrm{m}^{2}\right)$, declined in spring and remained low throughout the summer (Table 2). Chaoborus punctipennis and Hydracarina followed seasonal trends similar to the chironomids, with maximum winter populations and low summer populations 
(Table 2).

The low numbers of species and individuals during summer in Iittle Lake Barton were probably due to the emergence of nymphs and Chironomidae pupae and/or a result of low oxygen concentrations. Bottom dwellers with high respiratory demands (e.g. Hyalella azteca) would have to migrate upward in the water column to avoid low oxygen concentrations. During summer when oxygen concentrations were low in Little Lake Barton, hydrilla may have acted as an alternative habitat for benthic macroinvertebrates. Martin and Shireman (1976) found that chironomids, Gyralus sp. (a pulmonate snail), Hyalella azteca (an amphipod), mayfly nymphs and caddisfly larvae were abundant in hydrilla during summer in Lake Wales, a central Florida lake. Chironomids increased in abundance from $142 / \mathrm{kg}$ of hydrilla in May, 1976 to $865 / \mathrm{kg}$ of hydrilla in September, 1976 in Lake Wales. Gyralus sp., mayfly nymphs and caddisfly larvae were most abundant during winter in Little Lake Barton, as were chironomids, and were found in very few numbers during summer (Table 2). Hyalella azteca was only collected in May, $1977\left(4 / \mathrm{m}^{2}\right)$. Hyalella azteca and Gyralus sp. do not emerge and leave the environment like most aquatic insects; therefore, their continued abundance would be expected throughout the summer in Little lake Barton. Hyalella azteca normally reach maximum population density in bottom sediments of temperate lakes during 
Table 2. Monthly and annual mean munbers (organisms/ $\mathrm{m}^{2}$ ) of bonthic nacroinvertebrates collected in Little Lake Barton Erom January to December. 1977.

Numbers of crganisms $/ \mathrm{m}^{2}$

\begin{tabular}{|c|c|c|c|c|c|c|c|c|c|c|c|c|c|}
\hline Organians & Jan & Feb & Mar & Apr & May & Jun & Ju1 & Aug & Sept & Oct & Nov & Dec & Annuai \\
\hline \multicolumn{14}{|l|}{ O11gochaeta } \\
\hline bosfmeisstexi & 318 & 56 & 7 & 4 & 4 & 4 & 11 & 30 & 70 & 26 & 130 & 78 & 61 \\
\hline Nais sD. & 1932 & 951 & 7 & 70 & 32 & 33 & 0 & 30 & 0 & 41 & 270 & 215 & 302 \\
\hline \multicolumn{14}{|l|}{ Hirudinea } \\
\hline Dina parya & 0 & 0 & 0 & 0 & 4 & 0 & 0 & 0 & 0 & 0 & 0 & 0 & $<1$ \\
\hline Placondella phatera & 0 & 0 & 0 & 0 & 4 & 0 & 0 & 0 & 0 & 0 & 0 & 0 & $<1$ \\
\hline Helabdadla sp. & 0 & 0 & 0 & 0 & 0 & 4 & 0 & 0 & 0 & 0 & 0 & 0 & $<1$ \\
\hline \multicolumn{14}{|l|}{ Hydracarina } \\
\hline Unknown species & 233 & 888 & 11 & 0 & 167 & 52 & 63 & 26 & 19 & 78 & 26 & 67 & 136 \\
\hline \multicolumn{14}{|l|}{ Crustacea } \\
\hline $\begin{array}{l}\text { Hyaledla azteca } \\
\text { Padaemontes }\end{array}$ & 0 & 0 & 0 & 0 & 4 & 0 & 0 & 0 & c & 0 & 0 & 0 & $<1$ \\
\hline paludesus & 0 & 4 & 0 & 0 & 0 & 4 & 0 & 0 & 0 & 0 & 0 & 0 & $<1$ \\
\hline \multicolumn{14}{|l|}{ Insecta-Diptera } \\
\hline $\begin{array}{l}\text { Ablabesynia peleenis } \\
\text { iabrundinia }\end{array}$ & 30 & 26 & 0 & 0 & 0 & 4 & 0 & 4 & 0 & 11 & 4 & 19 & 8 \\
\hline neopdoselia & 0 & 0 & 0 & 0 & 0 & 0 & 0 & 0 & 0 & 0 & 0 & 4 & $<1$ \\
\hline sarsia bernexi & 0 & 11 & 0 & 0 & 0 & 0 & 0 & 0 & 0 & 0 & 0 & 0 & 1 \\
\hline Monopelopia boliekae & 4 & 22 & 0 & 0 & 0 & 0 & 0 & 0 & 0 & 0 & 0 & 0 & 2 \\
\hline Procladius sublettei & 0 & 4 & 0 & 4 & 0 & 4 & 4 & 33 & 0 & $7 a$ & 0 & 22 & 12 \\
\hline Tanypus scellacus & 0 & 4 & 0 & 0 & 0 & 4 & 0 & 0 & 0 & 0 & 0 & 0 & $<1$ \\
\hline 3ridta pax & 0 & 0 & 0 & 0 & 0 & 0 & 0 & 0 & 0 & 4 & 0 & 4 & $<\frac{1}{1}$ \\
\hline Cricotopus renus & 4 & 0 & 0 & 0 & 4 & 4 & 4 & 0 & 0 & 0 & 11 & 15 & 4 \\
\hline orthocladius ip. & 0 & 0 & 0 & 0 & 0 & 0 & 0 & 0 & 0 & 0 & 4 & 0 & $<1$ \\
\hline $\begin{array}{l}\text { Paectroctadius ap. } \\
\text { Paectroctadius }\end{array}$ & 0 & 0 & 0 & 0 & 0 & 0 & 0 & 0 & 0 & 0 & 4 & 26 & 3 \\
\hline chernadie & 7 & 7 & 0 & 0 & 0 & 0 & 0 & 0 & 0 & 0 & 4 & 4 & 2 \\
\hline atiamatexus & 1506 & 3304 & 237 & 459 & 93 & 26 & 0 & 0 & 0 & 37 & 107 & 514 & 524 \\
\hline & 0 & 0 & 0 & 0 & 0 & 0 & 0 & 0 & 0 & 0 & 0 & 7 & $<1$ \\
\hline$\frac{\text { Gxyprociadopelna }}{\text { ectrardyi }}$ & 44 & 30 & 0 & 4 & 0 & 0 & 0 & 0 & 0 & 19 & 26 & 100 & 19 \\
\hline piczorendipes ap. & 59 & 881 & 7 & 22 & 4 & 0 & 15 & 4 & 0 & 22 & 229 & 185 & 119 \\
\hline $\begin{array}{l}\text { Eanfeldia as. } \\
\text { Endochizon nus }\end{array}$ & 0 & 0 & 0 & 0 & 0 & 0 & 0 & 0 & 11 & 4 & 0 & 0 & $<1$ \\
\hline $\begin{array}{l}\text { nigricans } \\
\text { glyntersendipes }\end{array}$ & 0 & 0 & 0 & 0 & 4 & 0 & 0 & 0 & 0 & 0 & 0 & 0 & $<1$ \\
\hline paripes & 15 & 89 & 0 & 0 & 0 & 0 & 0 & 0 & 0 & 15 & 45 & 30 & 16 \\
\hline heleprasinus . & 0 & 0 & 0 & 0 & 0 & 0 & 0 & 0 & 0 & 0 & 4 & 0 & $<1$ \\
\hline $\begin{array}{l}\text { Luterberniebla } \\
\text { yasibennis }\end{array}$ & 0 & 0 & 0 & 0 & 0 & 0 & 4 & 0 & 0 & 0 & 0 & 0 & $<1$ \\
\hline$\frac{\text { Parachiconcmus }}{\text { dirtadatua }}$ & 163 & 111 & 4 & 0 & 11 & 0 & 11 & 33 & 30 & 19 & 48 & 41 & 39 \\
\hline $\begin{array}{l}\text { Paralauterbornielda } \\
\text { elachista }\end{array}$ & 0 & 0 & 0 & 0 & 0 & 0 & 0 & 0 & 0 & 0 & 4 & 0 & $<1$ \\
\hline Polvpestidum baterale & 4 & 0 & 0 & 0 & 0 & 0 & 0 & 4 & 0 & 0 & 7 & 4 & 2 \\
\hline Pgeudochironomus as. & 0 & 4 & 4 & 0 & 0 & 0 & 107 & 15 & 4 & 15 & 52 & 4 & 17 \\
\hline cloderanverarsue mo. & 0 & 4 & 0 & 78 & 0 & 0 & 11 & 0 & 0 & 7 & 11 & 7 & 10 \\
\hline inbocera ap. & 4 & 2098 & 30 & 7 & 19 & 0 & 0 & 0 & 0 & 30 & 30 & 26 & 187 \\
\hline Tanvearaue apg. & 0 & 318 & 0 & 0 & 0 & 0 & 59 & 0 & 4 & 11 & 285 & 39 & 64 \\
\hline 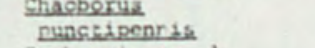 & 448 & 237 & 544 & 104 & 63 & 30 & 0 & 15 & 30 & 15 & 33 & 115 & 136 \\
\hline probazzat 3p. 1 & 0 & 4 & 4 & 7 & 0 & 0 & 0 & 0 & 0 & 0 & 0 & 19 & 3 \\
\hline Proberzis an. 2 & 0 & 0 & 0 & 0 & 11 & 7 & 0 & 4 & 4 & 0 & 0 & 7 & 3 \\
\hline Chrysops sp. & 0 & 4 & 0 & 0 & 0 & 0 & 0 & 0 & 0 & 0 & 0 & 0 & $<1$ \\
\hline
\end{tabular}

Insecta-Ephemeroptera

Gadilibaetias

Gaenis dininuta

Insecta-Odonata

Enaldagma ip.

Pexithenia seminole celithenis bextha

Insecta-Itemiptera

Sigara $\mathrm{g}$.

Insecta-Coleoptera Hedrevatus an.

Insecta-Trichoptera teptocella tavara cecatis ap.

Qrthotrichia sp. oxyethiza sp.

Gastropoda

Helisoma gn.

Gyratus sp.

Physa asp.

Vivinazus

Total

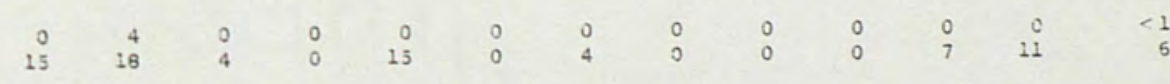

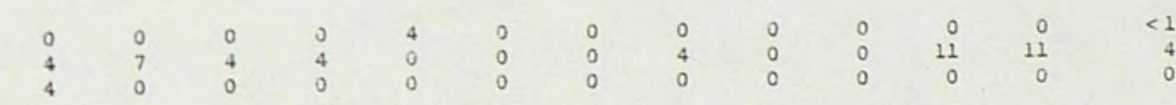

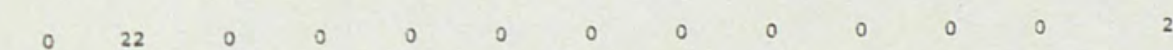

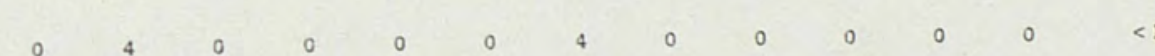

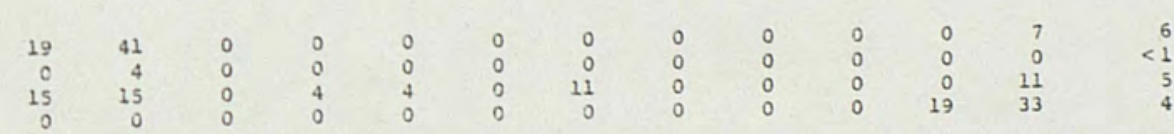

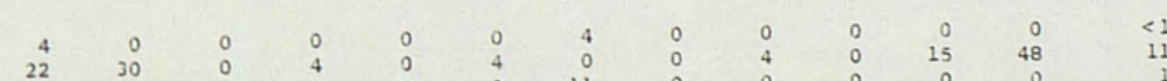

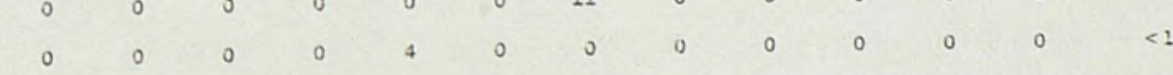

$\begin{array}{llllllllllllll}4858 & 9195 & 859 & 771 & 501 & 180 & 323 & 202 & 176 & 432 & 1386 & 1723 & -\end{array}$ 
Figure 3. Monthly mean numbers of organisms and species of benthic macroinvertebrates collected in Little Lake Barton from January to December, 1977. 


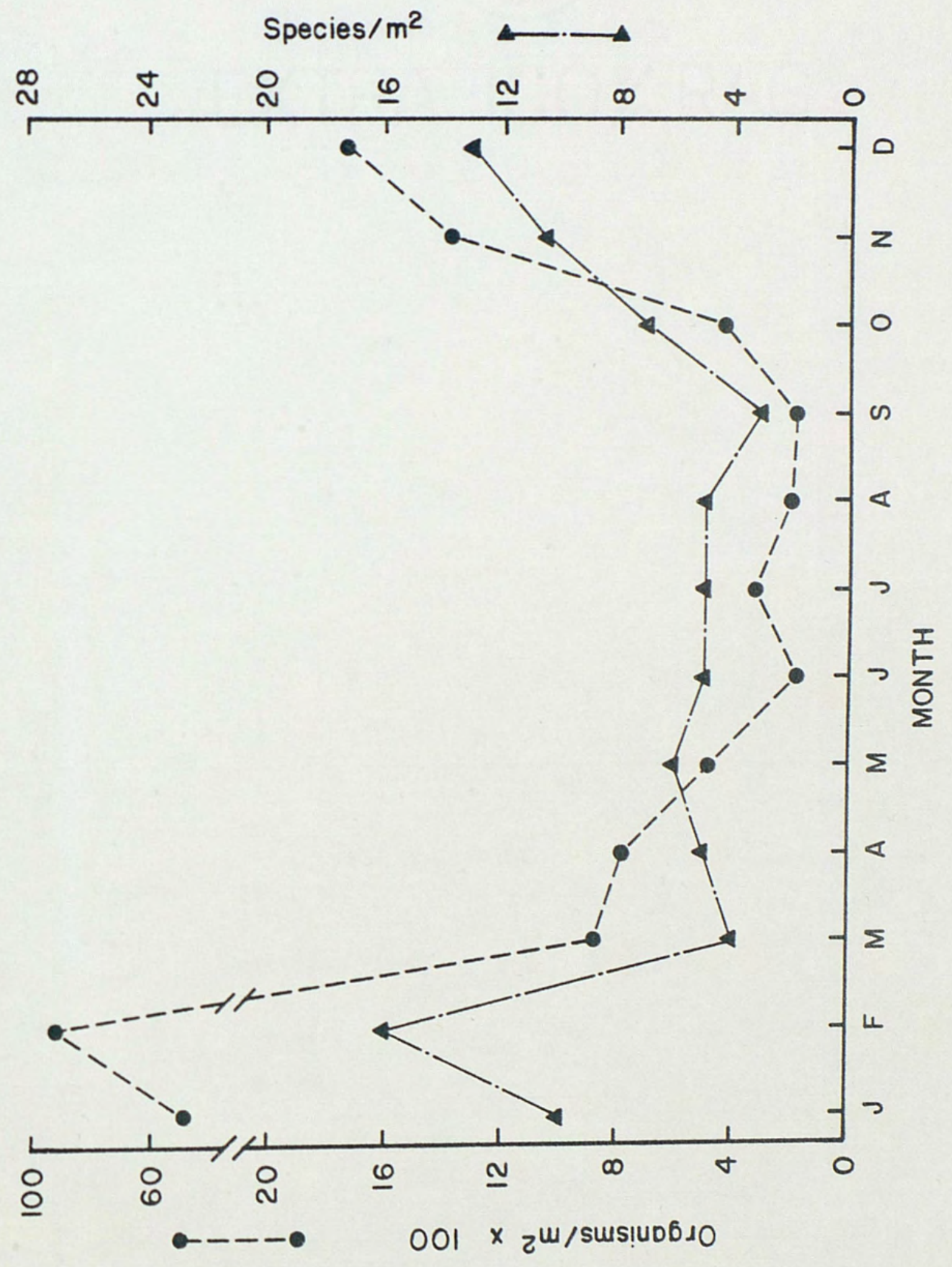


summer (Hargrave, 1970). Populations of snails increase in spring, fall and summer as reproductive periods occur (DeWit, 1954; Harmon, 1974). Although caddisflies, mayflies and chironomids emerge during summer, higher numbers of these organisms can be expected in summer because of their fluctuating growth cycles (Pennak, 1953; Roback, 1974; Wetzel, 1975). Chironomus stigmaterus, for instance, emerges all year long in Florida lakes (Beck and Beck, 1969).

The Shannon Index is a measure of the species diversity of a community; the value $\bar{d}$ generally ranges from $0-4$ in aquatic environments and approaches 0 when most individuals of a community belong to the same species (Wilhm and Dorris, 1968). The Simpson Index expresses the dominance of one or more species in a community and ranges from 0-1 (Simpson, 1949). Repetitive sampling of the same species results in a high Simpson Index and a low Shannon Index (Simpson, 1949; Wilhm and Dorris, 1968).

The annual mean Shannon Index for benthic macroinvertebrates in Little Lake Barton was 1.92 while the Simpson Index was 0.36. Osborne, et al. (1976) reported an annual mean Shannon Index of 1.92 and a Simpson Index of 0.38 for benthic macroinvertebrates in Spring Lake, a clean central Florida sand bottom lake. Although Shannon and Simpson Indices were similar between Little Lake Barton and Spring Lake, their species compositions were 
different. Benthic macroinvertebrate species in Spring Lake were dominated by Chironomidae, Trichoptera, Ephemeroptera and Odonata. The dominant species in Little Lake Barton were chironomids and oligochaetes. Chironomids and oligochaetes were also dominant in Lake Thonotosassa, a central Florida lake polluted by citrus processing and sewage effluent (Cowell, et al., 1975). However, diversity values were much lower for benthic macroinvertebrates in Lake Thonotosassa (less than 1.0) than in Little Lake Barton.

There was no significant difference $(P=0.05)$ between monthly mean values for the Shannon and Simpson Indices except between the months of February and March, 1977 (Figures 4 and 5). The low Shannon Index (0.75) in March, 1977 was the result of a decrease in numbers of species as well as individuals, possibly due to cold weather conditions in late February (Figure 3). Chaoborus punctipennis and Chironomus stigmaterus were dominant in March, 1977 and probably caused the high Simpson Index (0.78) for that month. In winter and spring, species diversity is usually higher than in summer due to good water quality, abundant food sources and the fact that many species emerge as adults in summer (Ransom and Dorris, 1972). Osborne, et al. (1976) reported diversity values lower than 2.0 for six oligotrophic lakes in central Florida during summer. Low diversity values were attributed to low species numbers, 
Figure 4. Monthly means ( $\pm 95 \%$ confidence limits) of the Shannon Index for benthic macroinvertebrates in Little Lake Barton, January to December, 1977. 


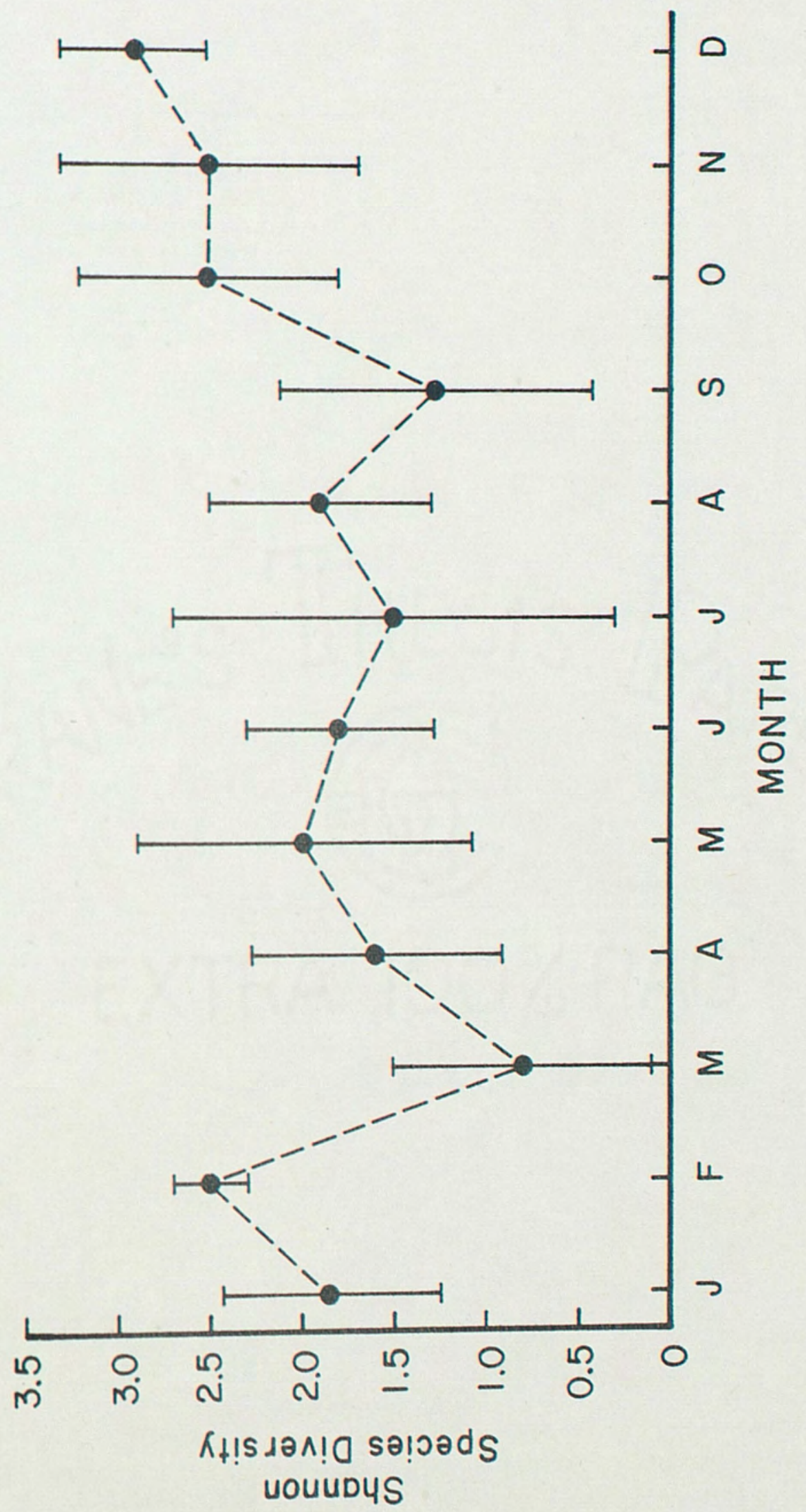


Figure 5. Monthly means ( $\pm 95 \%$ confidence limits) of the Simpson Index for benthic macroinvertebrates ir Little Lake Barton, January to December, 1977. 


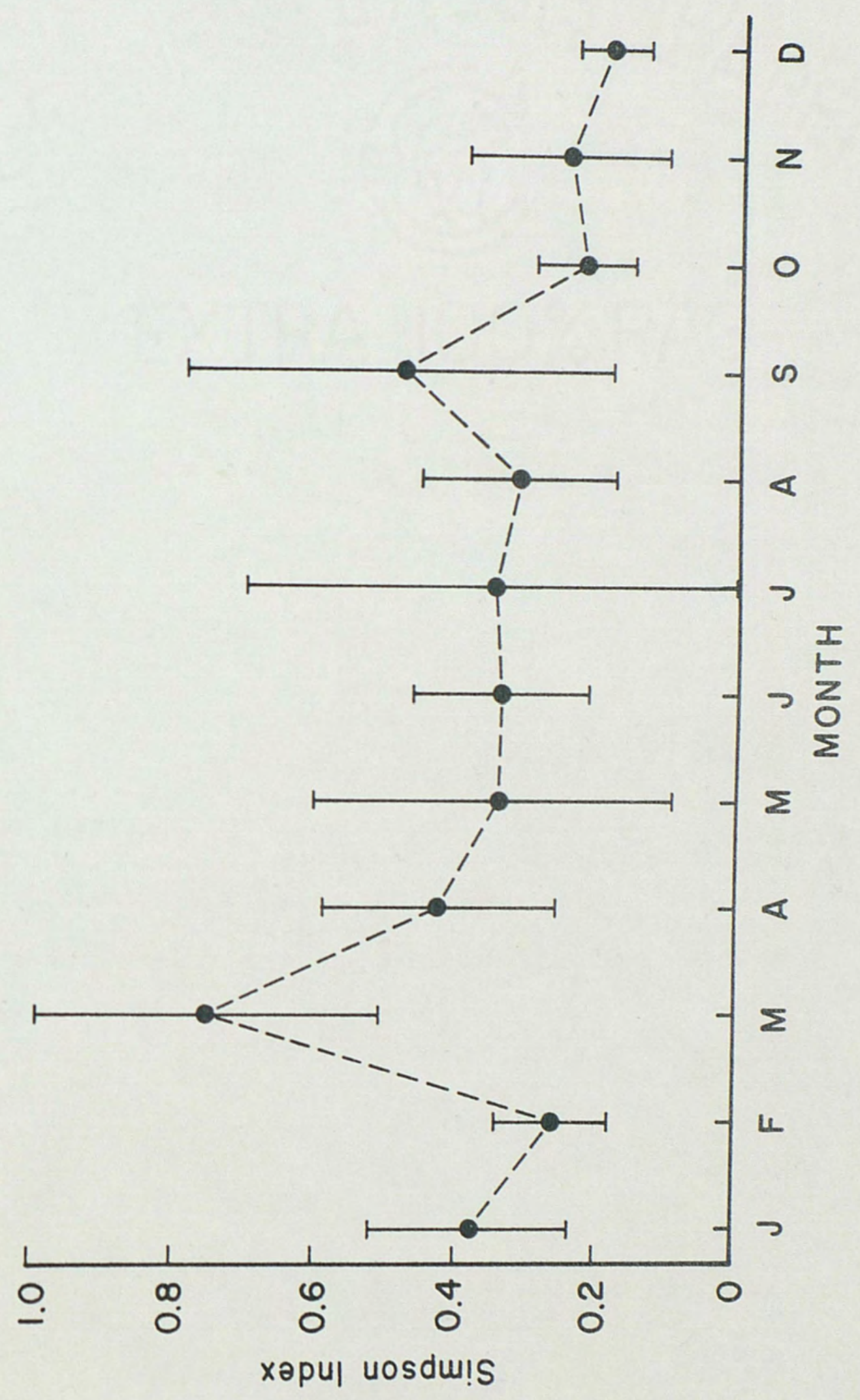


resulting from summer stress conditions. The low number of species and number of individuals of the species in Little Lake Barton may have resulted from many of the benthic macroinvertebrates inhabiting hydrilla instead of residing in the sediment. Summer emergence and summer stress conditions probably aided in causing low diversity. 
SUIIMARY

The growth of hydrilla influenced changes in oxygen concentrations, alkalinity, inorganic carbon, nutrients, $\mathrm{pH}$, turbidity, color and light penetration in Little Lake Barton, Florida. These physicochemical factors affected the species diversity and abundance of benthic macroinvertebrates. During winter when hydrilla biomass was low, total alkalinity and inorganic carbon concentrations were high while pH was low. Chlorophyll concentrations increased since nutrients utilized in hydrilla metabolism during the growing season were available for phytoplankton growth. This higher phytoplankton density in winter caused increased turbidity and color. Hydrilla grew rapidly when water temperatures increased in spring. By summer the lake was covered with dense mats of hydrilla which reduced water circulation and light penetration to the bottom. As phytoplankton populations decreased, turbidity decreased. Total alkalinity and inorganic carbon decreased while $\mathrm{pH}$ increased.

Species diversity and abundance of benthic macroinvertebrates was greatest in winter. Chironomids and oligochaetes numerically dominated the benthos; twenty-seven of the 54 taxa collected were members of the Chironomidae 
family. Species diversity and abundance of benthic macroinvertebrates were lowest in summer. Although many benthic macroinvertebrates emerge as adults in summer, some may have life cycles that fluctuate enough to produce substantial larvae numbers during summer. Low species diversity and abundance may have resulted from organisms with high respiratory demands inhabiting hydrilla instead of bottom sediments during stressful conditions. Oxygen conditions were often below tolerance levels for many benthic macroinvertebrates during late summer and early fall when shading by hydrilla reduced community photosynthesis. 
Appendix I. Monthly means of physicochemical and chlorophyll parameters in Little Lake Barton, January to December, 1977. 
Figure 6. Monthly mean values ( $\pm 95 \%$ confidence limits) for turbidity from January to December, 1977 in Little Lake Barton. 


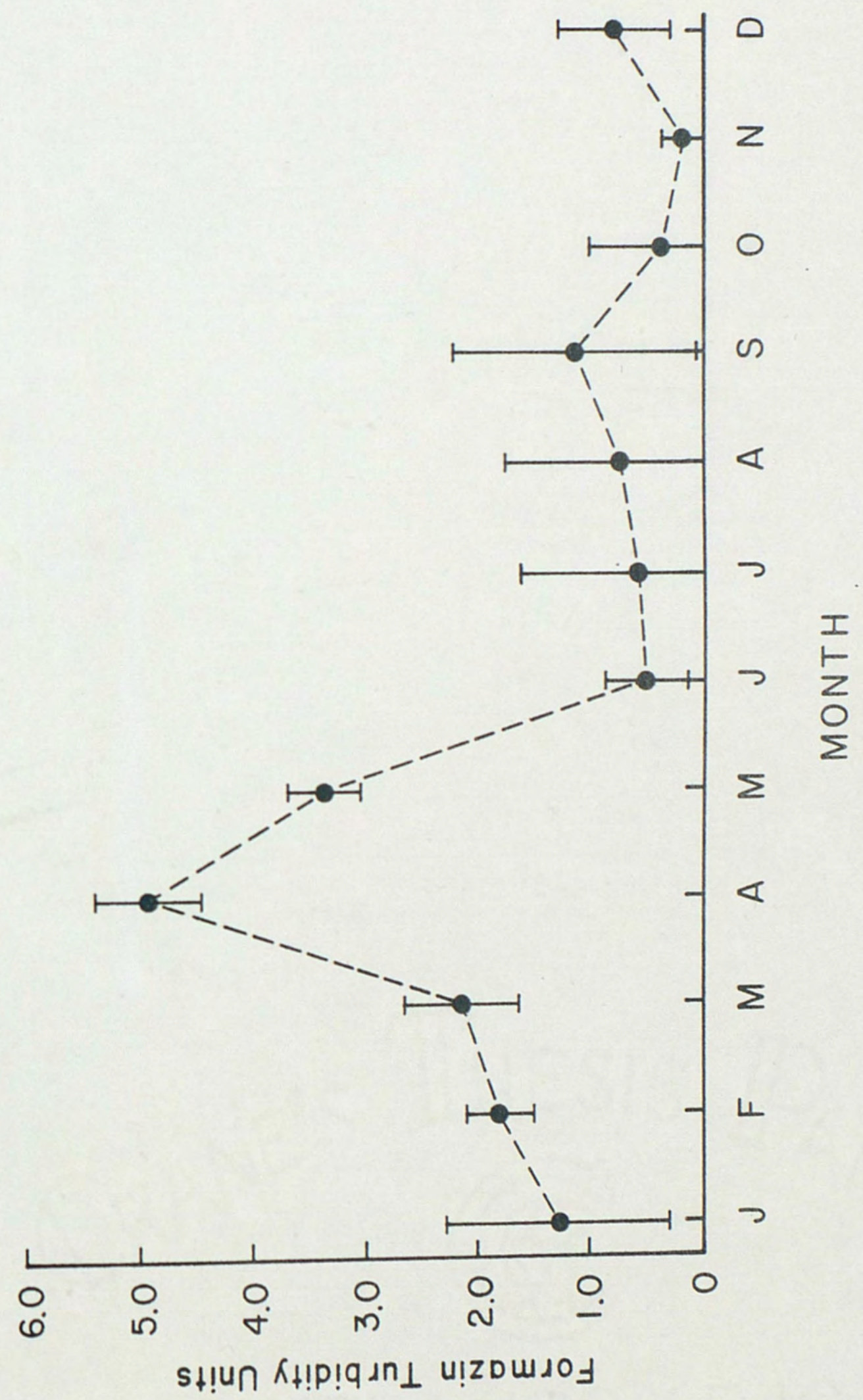


Figure 7. Color monthly mean values $( \pm 95 \%$ confidence limits) in Little Lake Barton, January to December, 1977 . 


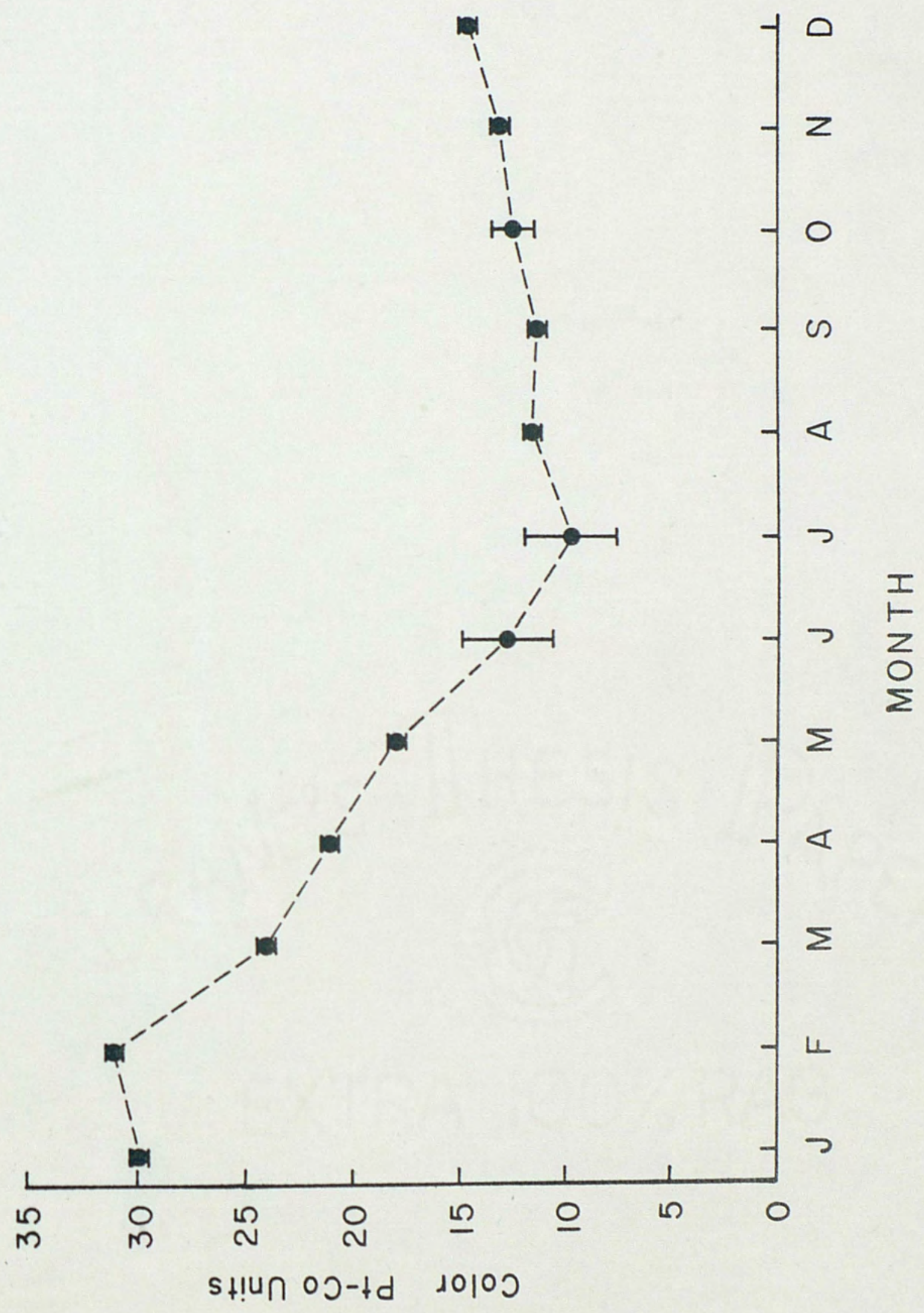


Figure 8. Monthly means and $95 \%$ confidence intervals for chlorophyll concentrations in Little Lake Barton from January to December, 1977. 


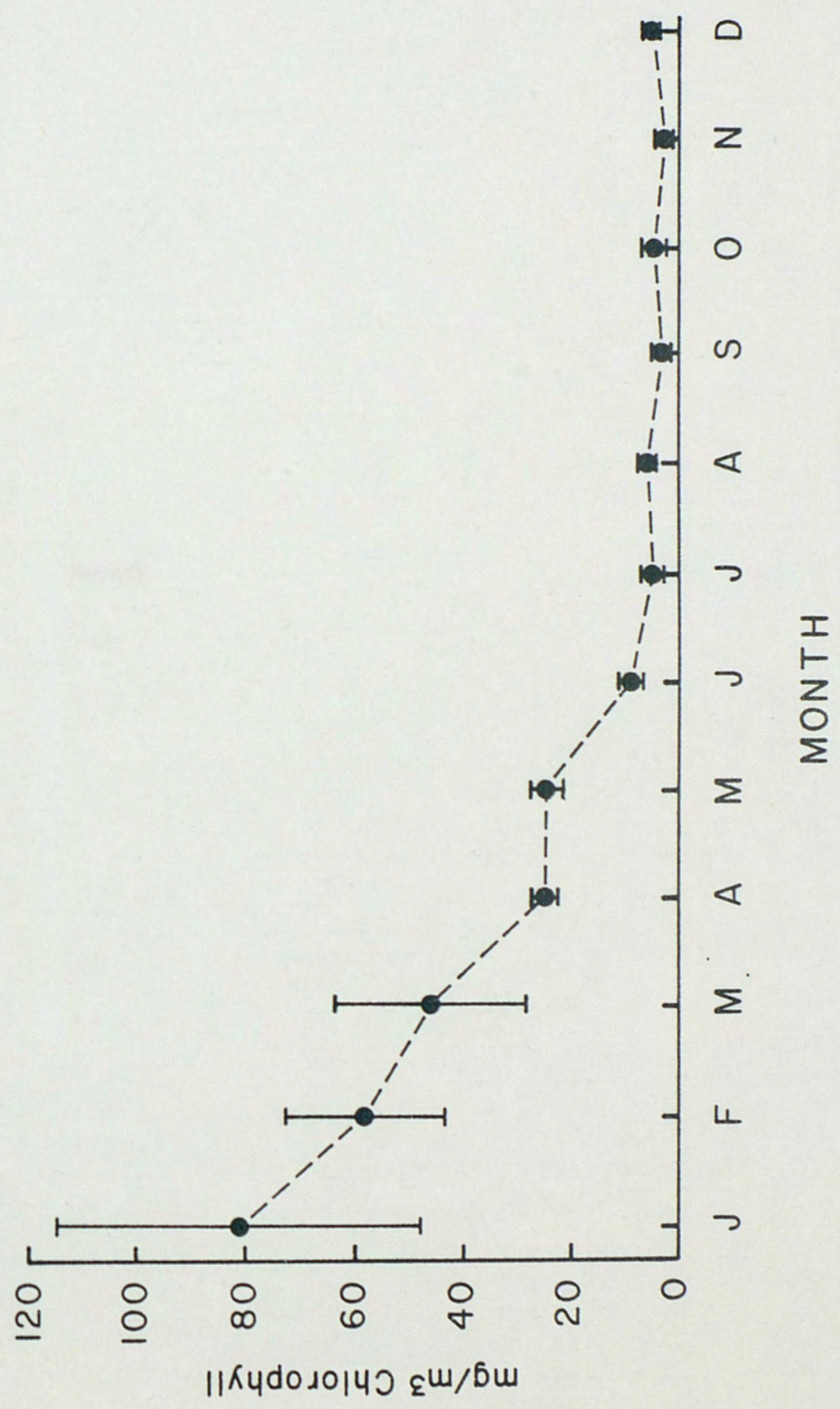


Figure 9. Total alkalinity monthly means ( $\pm 95 \%$ confidence limits) in Little Lake Barton, January to December, 1977 . 


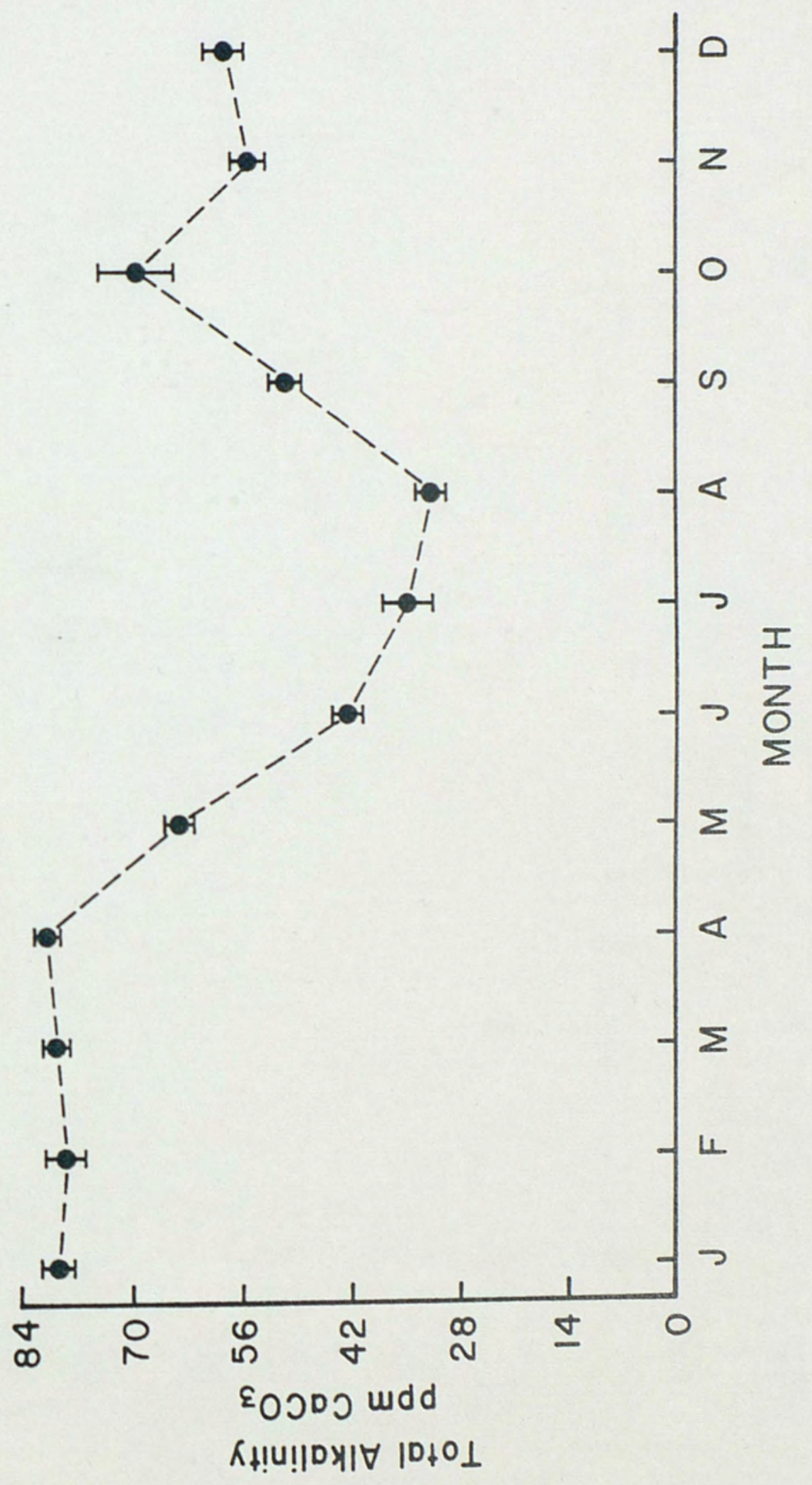


Figure 10. Inorganic carbon monthly means and $95 \%$ confidence limits in Little Lake Barton from January to December, 1977. 


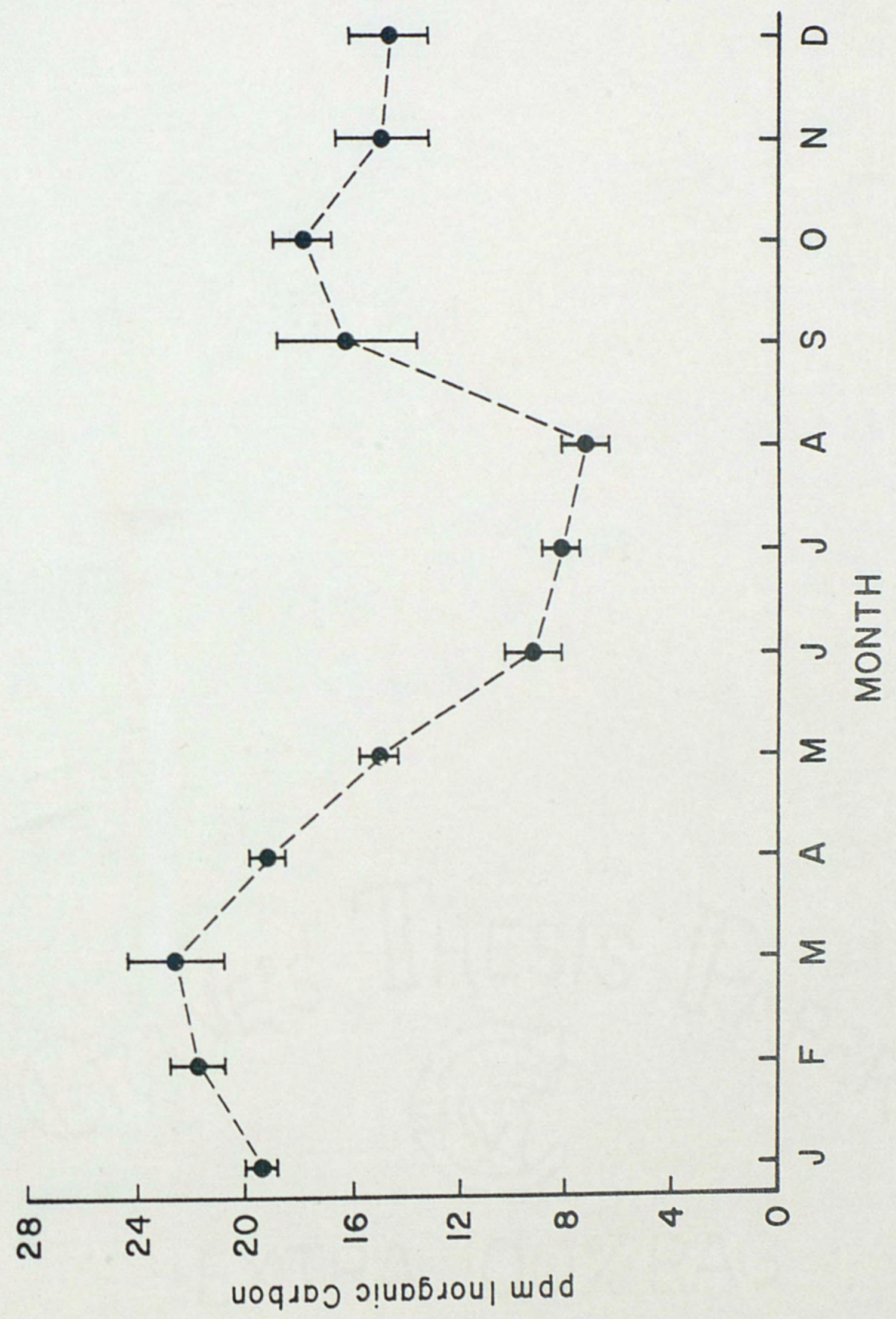


Figure 11. Monthly means for hydrogen ion concentrations ( $\pm 95 \%$ confidence limits) from January to December, 1977 in Little Lake Barton. 


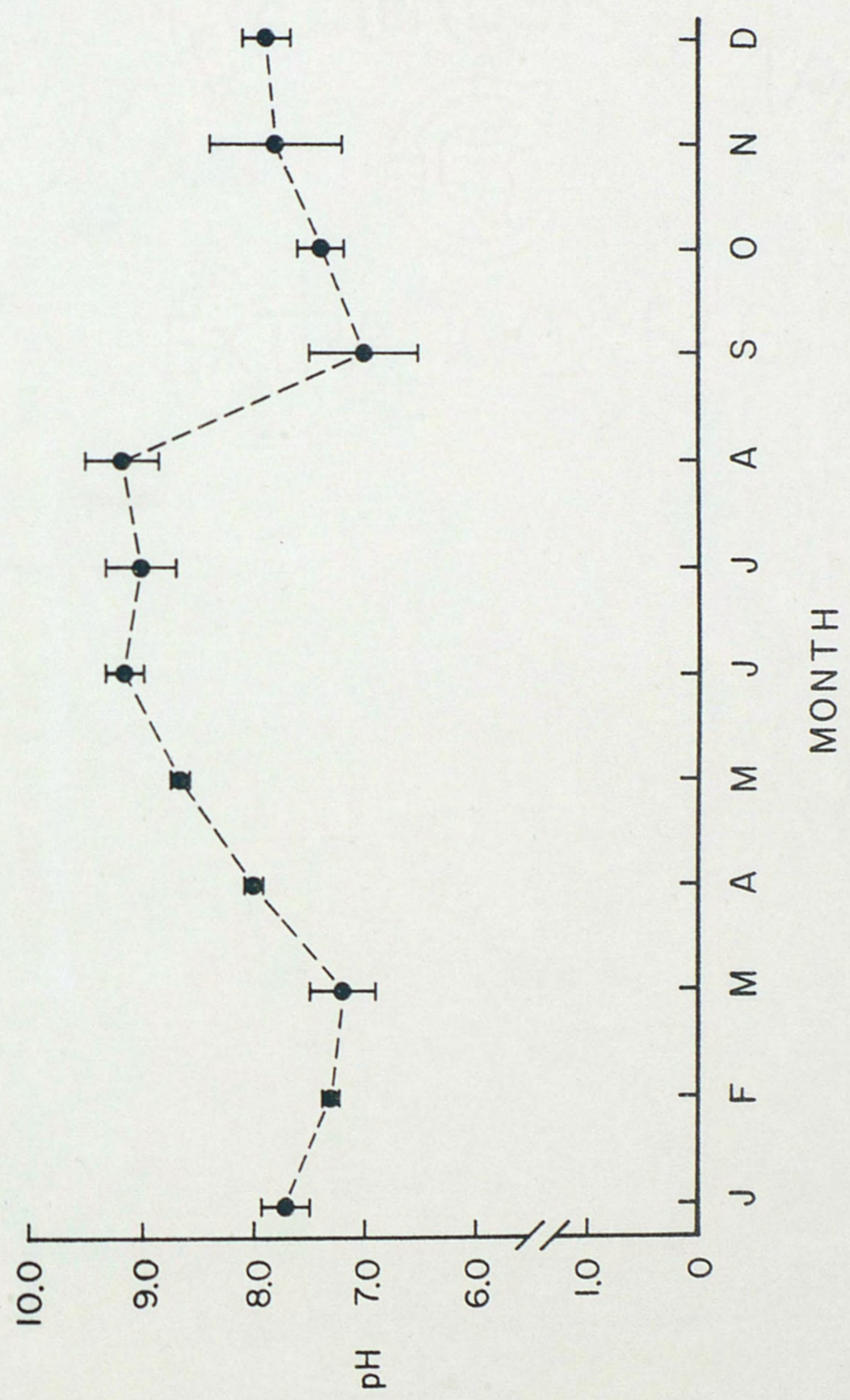


Figure 12. Monthly means and $95 \%$ confidence limits for bicarbonate and carbonate alkalinity from January to December, 1977 in Little Lake Barton. 


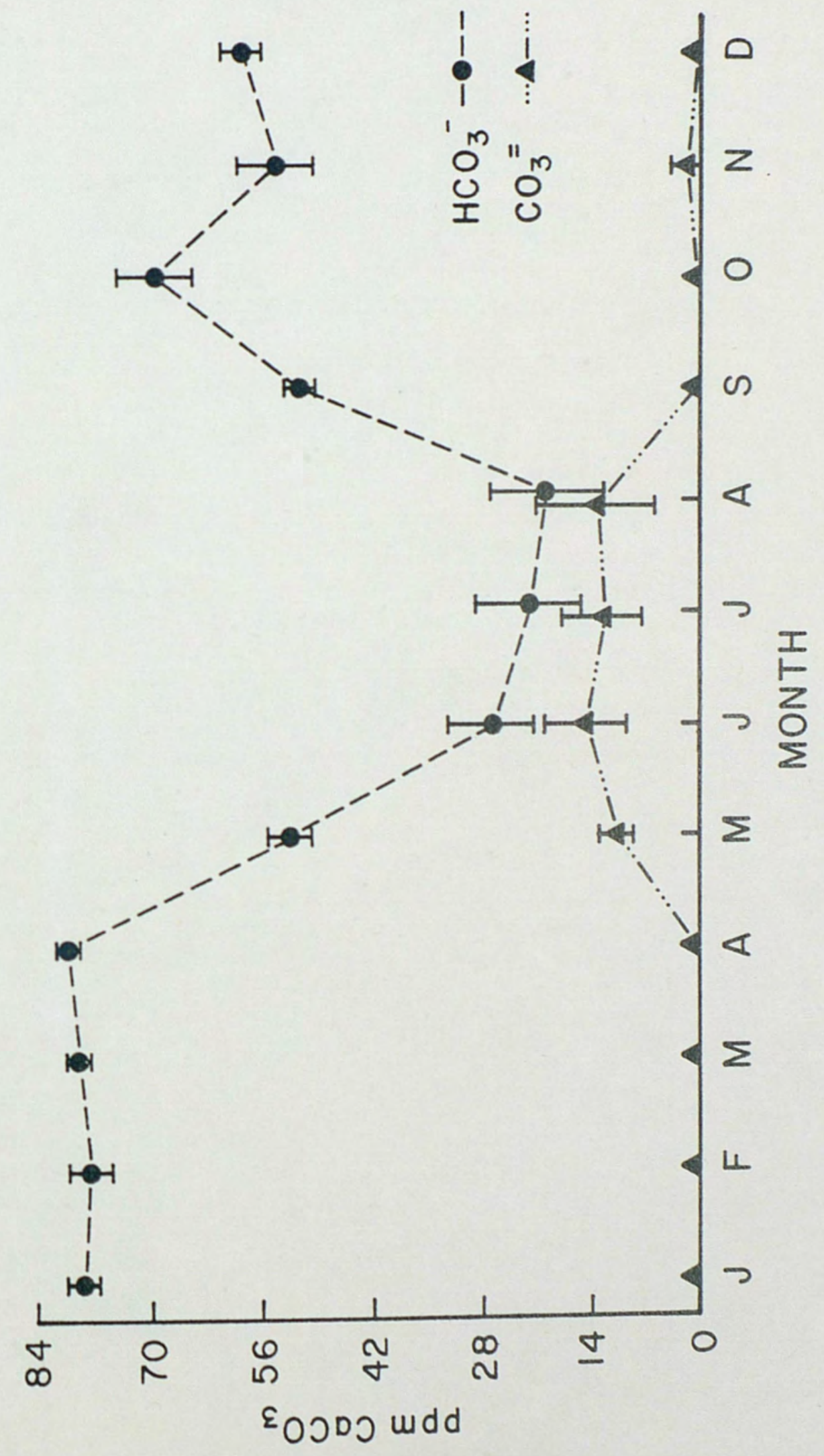


Figure 13. Monthly means for specific conductivity ( $\pm 95 \%$ confidence limits) in Little Lake Barton from January to December, 1977. 


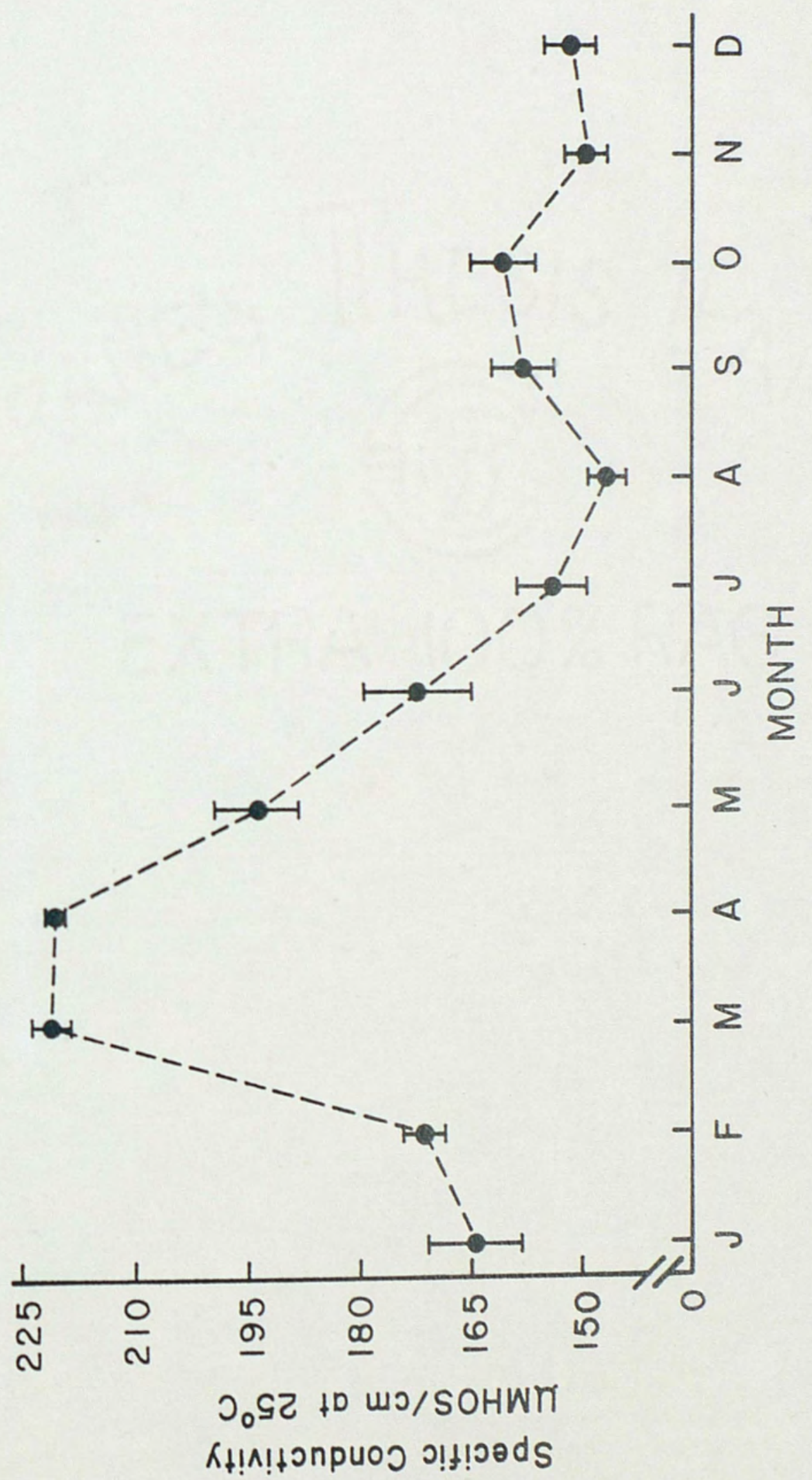


Figure 14. Monthly means ( $\pm 95 \%$ confidence limits) for orthophosphate concentrations from January to December, 1977 in Little Lake Barton. 


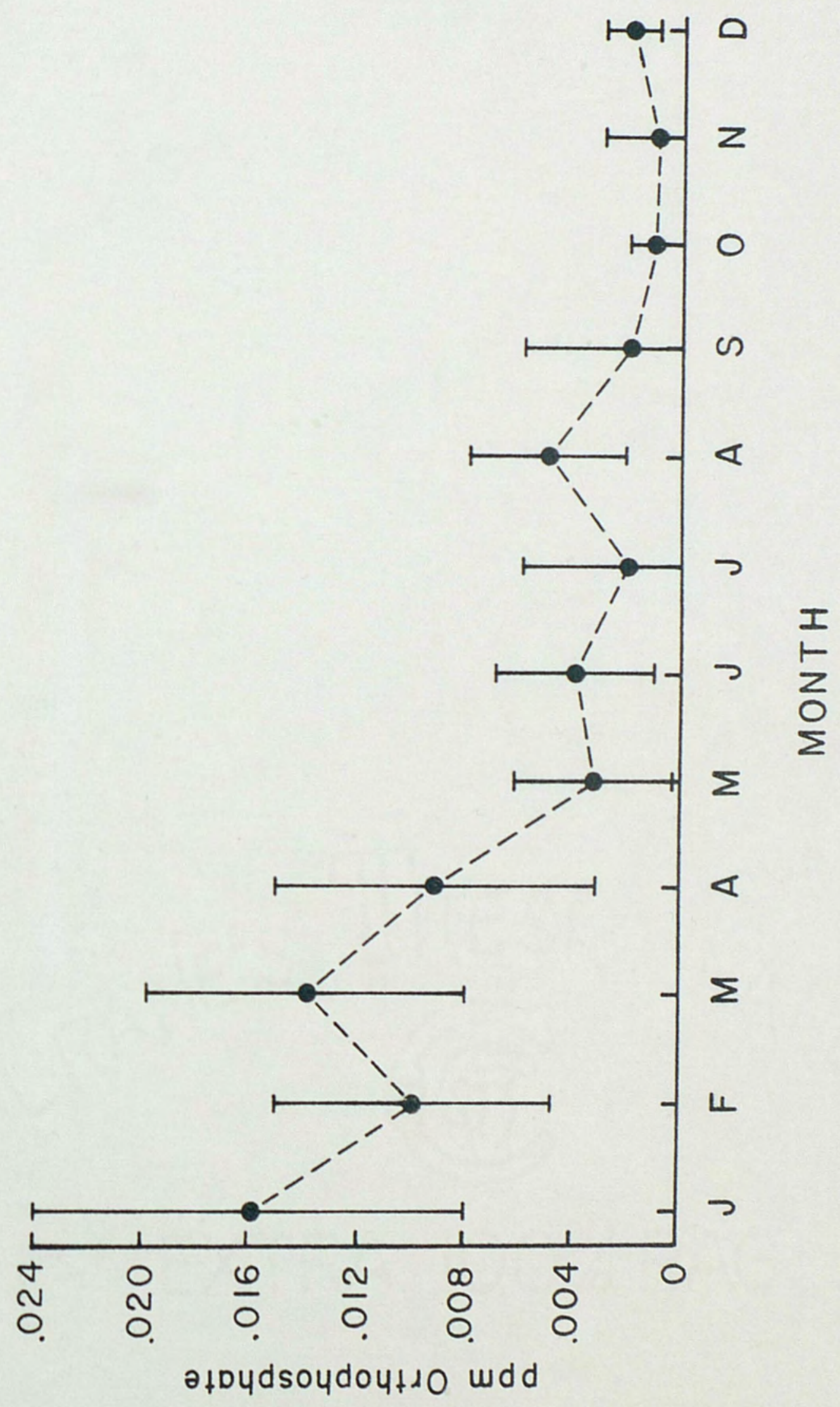


Figure 15. Monthly mean values ( $\pm 95 \%$ confidence limits) for nitrate-nitrogen concentrations from January to December, 1977 in Little Lake Barton. 


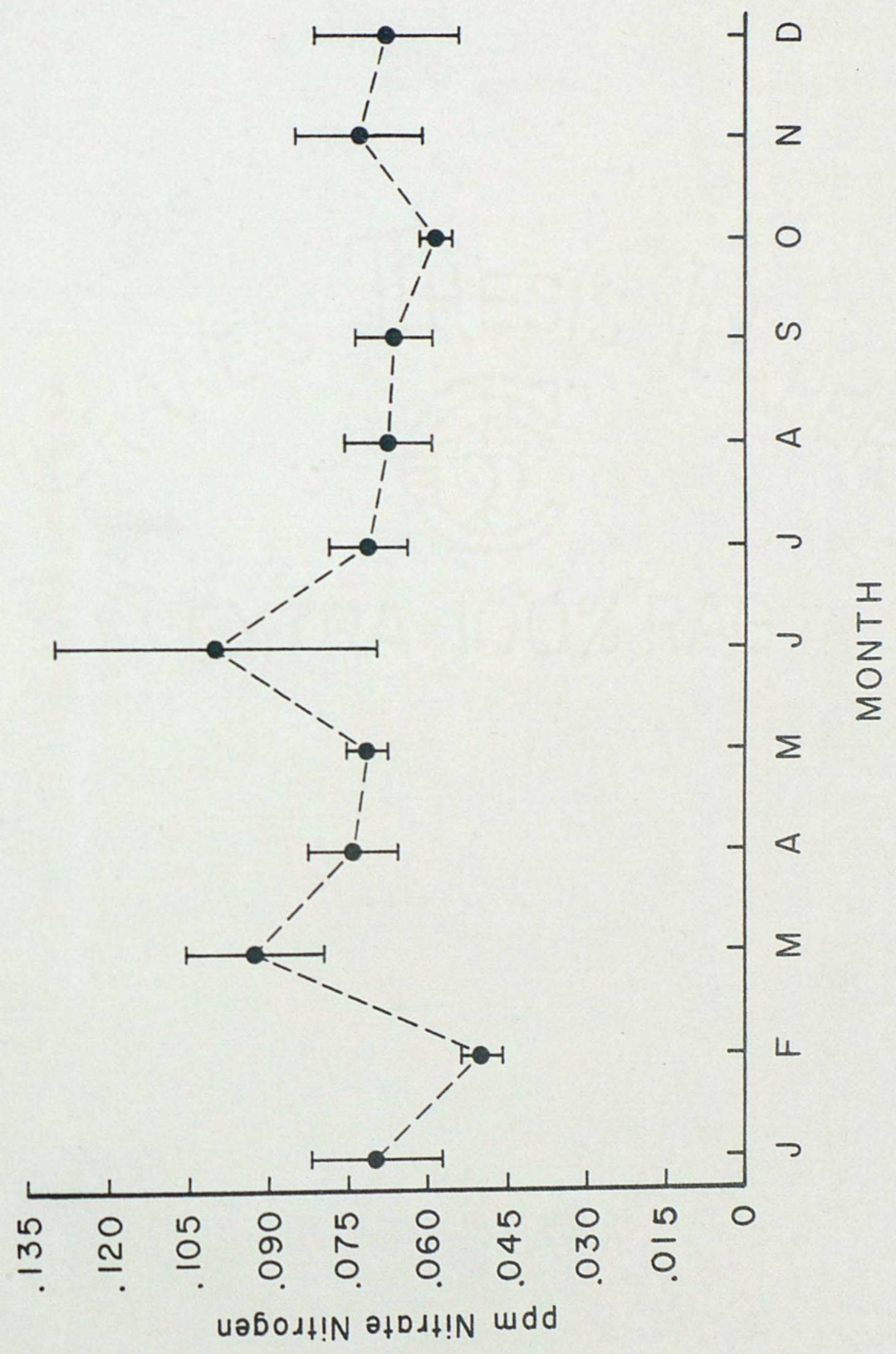


Figure 16. Nitrite-nitrogen monthly means and $\pm 95 \%$ confidence limits in Little Lake Barton from January to December, 1977. 


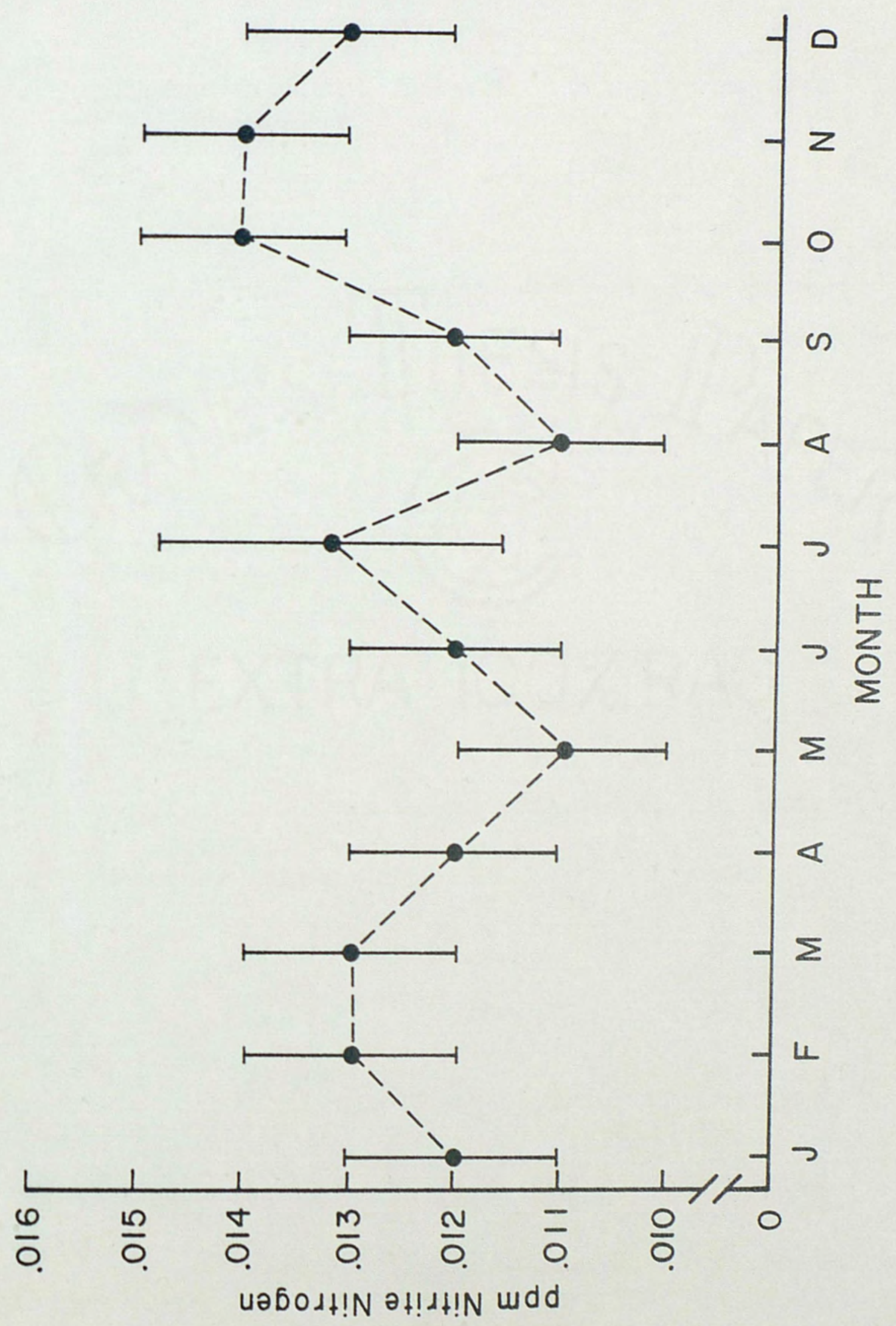


Figure 17. Monthly mean dissolved oxygen concentrations ( $\pm 95 \%$ confidence limits) from January to December, 1977 in Little Lake Barton. 

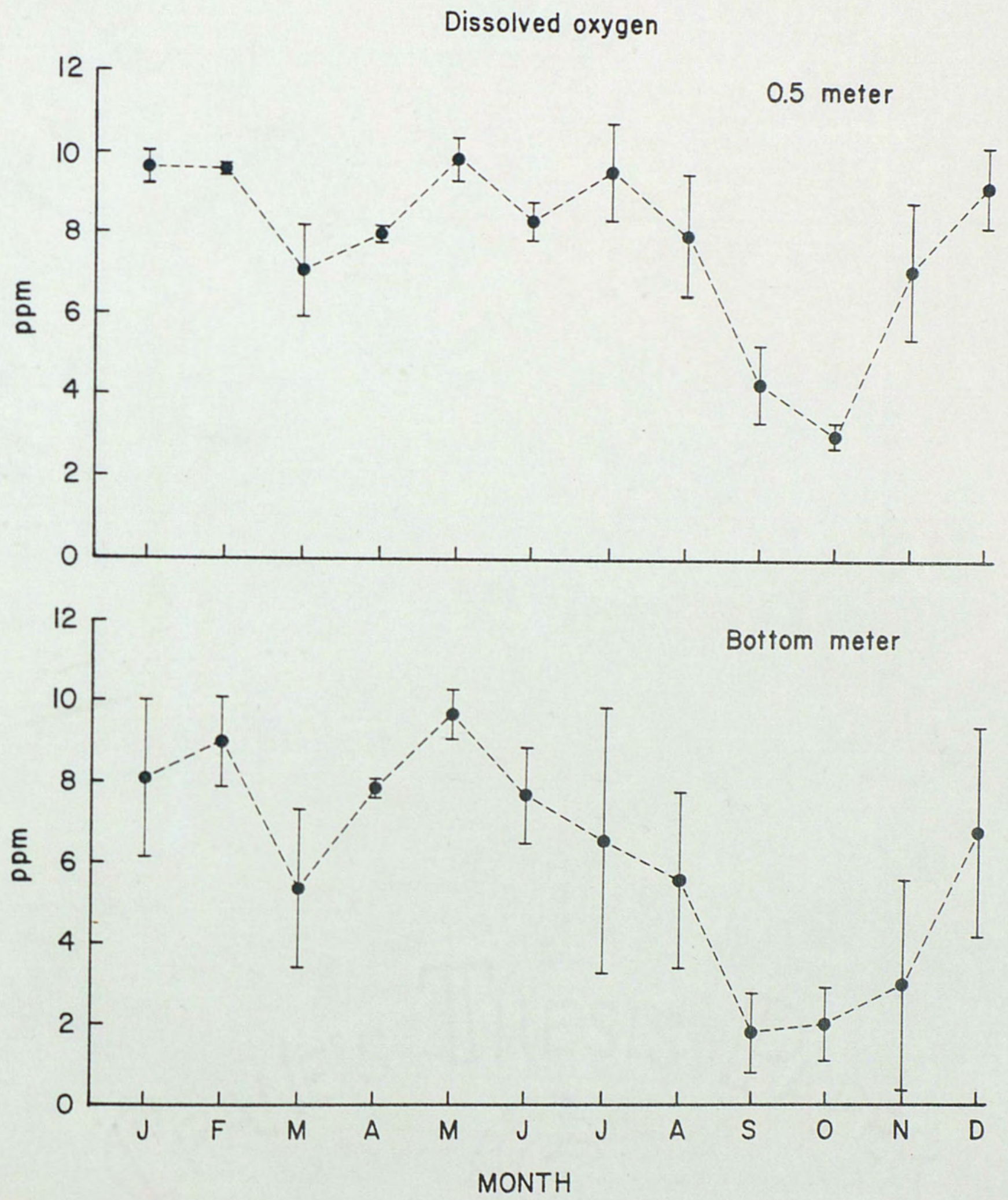
Figure 18. Temperature monthly means and $95 \%$ confidence intervals from January to December, 1977 in Little Lake Barton. 
Temperature
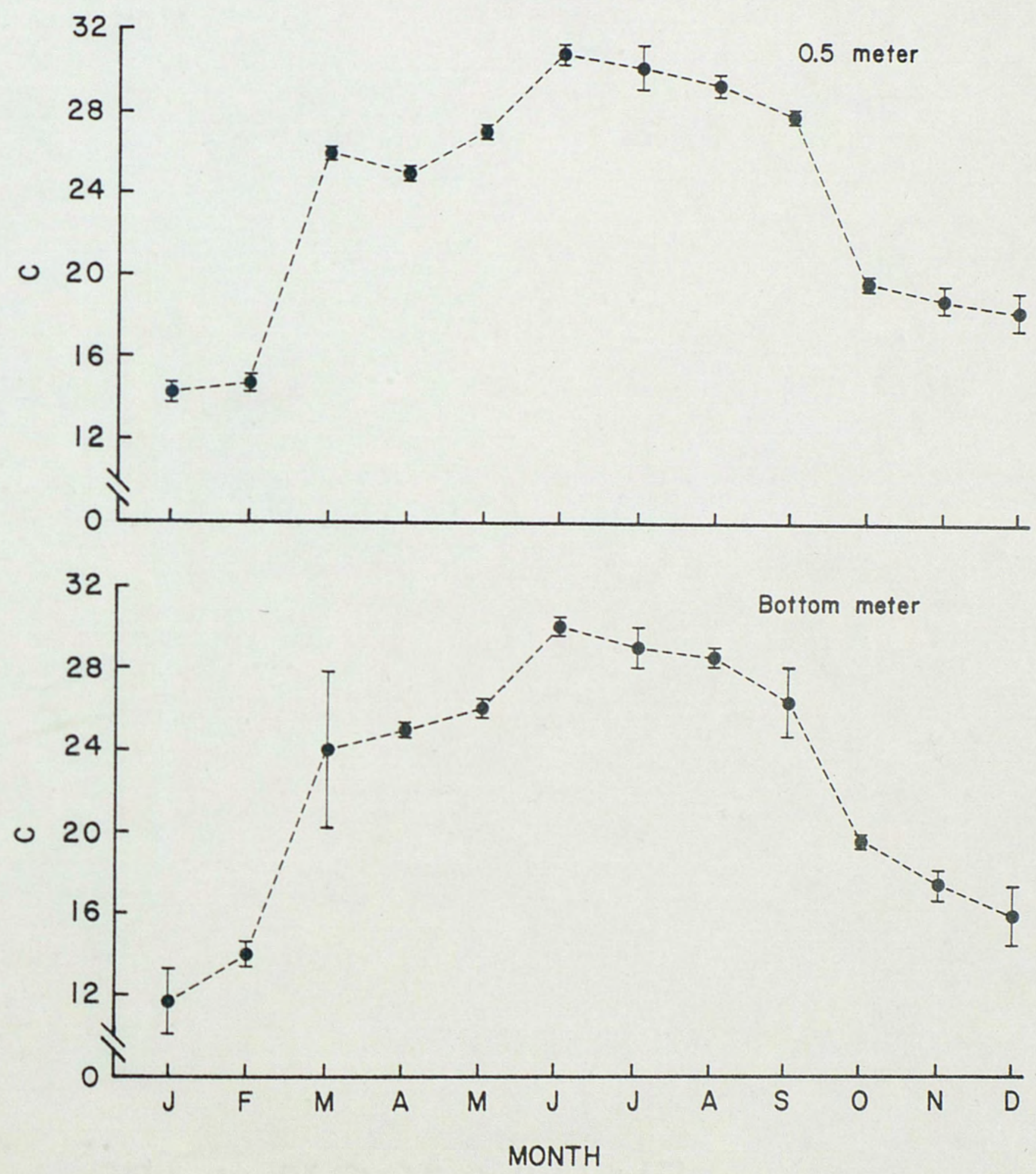
Appendix II. Classification of benthic macroinvertebrates collected in Little Lake Barton from January to December, 1977. 
Annelida

Oligochaeta

Plesiopora Turbificidae Naididae

Hirudinea

Arhynchobdellida Erpobdellidae

Rhynchobdellida

Glossiphoniidae

\section{Arthropoda}

Arachnoidea

Hydracarina

Crustacea

Amphipoda

Talitridae

Decapoda

Palaemonidae

Insecta

Diptera

Chironomidae

Tanypodinae

Orthocladiinae

Chironominae

Insecta

Chaoboridae

Limnodrilus hoffmeisteri

Nais sp.

Dina Parva

Placobdella phalera

Helabdella sp.

Unknown species

Hyalella azteca

Palaemonetes paludosus

Ablabesymia peleenis

Labrundinia neopilosella

Larsia berneri

Monopelopia boliekae

Procladius sublettei

Tanypus stellatus

Brilla par

Cricotopus remus

Orthocladius sp.

Psectrocladius sp.

Psectrocladius vernalis

Chironomus stigmaterus

Cryptochironomus fulvus

Cryptocladopelma edwardsi

Dicrotendipes sp.

Einfeldia sp.

Endochironomus nigricans

Glyptotendipes paripes

Goeldichironomus holoprasinus

Lauterborniella varipennis

Parachironomus hirtalatus

Paralauterborniella elachista

Polypedilum halterale

Pseudochironomus sp.

Cladotanytarsus sp.

Nimbocera sp.

Tanytarsus spp.

Chaoborus punctipennis 
Diptera

Chironomidae Ceratopogonidae Tabanidae Ephemeroptera Baetidae Caenidae Odonata Agrionidae Libellulidae

Coleoptera Dytiscidae Hemiptera Corixidae Trichoptera Leptoceridae

Hydroptilidae

Mollusca

Gastropoda

Pulmonata

Physidae

Planorbidae

Ctenobranchiata Viviparidae

Probezzia sp. 1

Probezzia sp. 2

Chrysops sp.

Callibaetis floridanus

Caenis diminuta

Enallagma sp.

Perithemis seminole

Celithemis bertha

Hydrovatus sp.

Sigara sp.

Leptocella tavara

oecetis sp.

Orthotrichia sp.

oxythira sp.

Physa sp.

Helisoma sp.

Gyralus sp.

Viviparus georgeanus wareanus 
LITERATURE CITED 
American Public Health Association. 1971. Standard Methods for the Examination Water and Wastewater. American Public Health Association.

Bachmann, R.W. 1959. Unpublished paper. Dept. of Zoology University of Michigan.

Ball, R.C. and D.W. Hayne. 1952. Effects of the removal of the fish population on the fish-food organisms of a lake. Ecology. 33:41-48.

Beck, E.C. and W.M. Beck, Jr. 1969. The Chironomidae of Florida. II. The nuisance species. Fla. Entomol. $52: 1-11$.

Beck, W.M. Jr. 1969. Stream monitoring biological parameters. Florida's Environmental Engineering Conference on Water Pollution Control. Fla. Eng. Ind. Bull. Ser. 135:1-68.

Beck, W.M. Jr. 1976. Biology of the larval chironomids. State of Florida Dept. of Environmental Regulation Tech. Ser. 1:1-58.

Beck, W.M. Jr. and E.C. Beck. 1966. Chironomidae (Diptera) of Florida. I. Pentaneurini (Tanypodiae). Bull. Fla. St. Mus. 10:305-379.

Beeton, A.M. 1965. Eutrophication of the St. Lawrence Great Lakes. Limnol. Oceanogr. 10:240-254.

Berner, I. 1950. The mayflies of Florida. University of Florida Studies. Bio. Sci. Ser. 4:1-267.

Blackburn, R.D., L.W. Weldon, R.R. Yeo and T.M. Taylor. 1969. Identification and distribution of certain similar appearing submersed aquatic weeds in Florida. Hyacinth Contr. J. 8:17-21.

Bowes, G., T.K. Van, I.A. Garrard and W.E. Haller. 1977. Adaption to low light levels by hydrilla. J. Aquatic Plant Mgt. 15:32-35.

Brinkhurst, R.0. 1974. Factors mediating interspecific aggregation of Turbificid oligochaetes. J. Fish. Res. Bd. Canada. 31:460-462.

Brinkhurst, R.O. and D.G. Cook. 1974. Aquatic earthworms (Annelida:0ligochaeta), p. 143-156. In C.W. Hart, Jr. and S.I.H. Fuller (eds.), Pollution ecology of freshwater intertebrates. Academic Press. 
Brinkhurst, R.O. and B.G.M. Jamieson. 1971. Aquatic Oligochaeta of the world. University of Toronto Press.

Busemi, P.A. 1958. Littoral oxygen depletion produced by a cover of Elodea canadensis. Oikos. 9:239-245.

Cole, G.A. and J.C. Underhill. 1965. The summer standing crop of sublittoral and profundal benthos in Lake Itasca, Minnesota. Limnol. Oceanogr. $10: 591-597$.

Cowell, B.C., C.W. Dye and R.C. Adams. 1975. A synoptic study of the limnology of lake Thonotosassa, Florida. I. Effects of primary treated sewage and citrus wastes. Hydrobiologia. 46:301-345.

Cummins, K.W. 1973. Trophic relations of aquatic insects. Ann. Rev. Entomol. 18:183-206.

DeWit, R.M. 1954. Reproduction, embryonic development and growth in the pond snail, Physa gyrina Say. Trans. Amer. Microsc. Soc. 37:124-137.

Edmondson, W.T. (ed.). 1959. Freshwater biology. John Wiley and Sons.

Gaufin, A.R. and C.M. Tarzwell. 1955. Environmental changes in a polluted stream during winter. Amer. Midland Nat. 54:78-88.

Gerking, S.D. 1962. Production and food utilization in a population of bluegill sunfish. Ecol. Monogr. $32: 31-78$.

Goulder, R. 1969. Interactions between the rates of production of a freshwater macrophyte and phytoplankton in a pond. Oikos. 20:300-309.

Hall, D.J., W.E. Cooper and E.E. Werner. 1970. An experimental approach to the production dynamics and structure of freshwater animal communities. Limnol. Oceanogr. 15:839-928.

Haller, W.T. 1976. Hydrilla. A new and rapidly spreading aquatic weed problem. Institute of Food and Agricultural Sciences, Gainesville, Florida. Circular $5-245,1-11$. 
Haller, W.T. and D.I. Sutton. 1975. Community structure and competition between Hydrilla and Vallisneria. Hyacinth Contr. J. 13:48-50.

Hargrave, B.T. 1970. The utilization of benthic microflora by Hyalella azteca (Amphipoda). J. Anim. Ecol. $39: 427-437$.

Harman, W.N. 1974. Snails (Mollusca:Gastropoda), p. 275312. In C.W. Hart, Jr. and S.I.H. Fuller (eds.), Pollution ecology of freshwater invertebrates. Academic Press.

Hasler, A.D. and E. Jones. 1949. Demonstration of the antagonistic action of large aquatic plants on algae and rotifers. Ecology. 30:359-364.

Hough, P.A. 1974. Photorespiration and productivity in submersed aquatic vascular plants. Limnol. Oceanogr. 19:912-927.

Jonasson, P.M. 1969. Bottom fauna and eutrophication, p. 274-305. In Eutrophication: causes, consequences and correctives. National Academy of Science.

Leighty, R.A. 1960. Soil Survey of Orange County, Florida. U.S. Dept. Agriculture Soil Conserv. Service Ser. No. 5 . U.S. GPO.

Nacan, T.T. 1961. Factors that limit the range of freshwater animals. Biol. Rev. 36:151-198.

Nartin, R.G. and J.V. Shireman. 1976. A quantitative sampling method for hydrilla - inhabiting macroinvertebrates. J. Aquatic Plant Ngt. 14:16-19.

Nason, W.T. 1968. An introduction to the identification of chironomid larvae. U.S. Dept. of Interior.

Division of Pollution Surveillance FWPCA. U.S. GPO.

NcLachlan, A.J. 1969. The effect of aquatic macrophytes on the variety and abundance of benthic fauna in a newly created lake in the tropics (Lake Kariba). Arch. Hydrobiol. 66:212-231.

Mclachlan, A.J. 1975. The role of aquatic macrophytes in the recovery of the benthic fauna of a tropical lake after a dry phase. Limnol. Oceanogr. 20:54-63. 
Needham, J.G. and M.J. Westfall, Jr. 1955. A manual of the dragonfly nymphs of North America including the Greater Antilles and the provinces of the Mexican border. University of California Press.

Osborne, J.A., J.J. Daigle and J.R. Startzman. 1976. Benthic macroinvertebrate abundance and species diversity in a central Florida lake. Abstract of the Annual Meeting, Florida Academy of Sciences, St. Petersburg, Florida.

Osborne, J.A., M.P. Wanielista and Y.A. Yousef. 1976. Benthic fauna species diversity in central Florida lakes in summer. Hydrobiologia. 48:125-129.

Osborne, J.A. and N.M. Sassic. 1979. Biological control of Hydrilla verticillata Royle with grass carp (Ctenopharyngodon idella Val.). J. Aquat. Plant Ngt. $17: 45-48$.

Otsuki, A. and R.G. Wetzel. 1974. Calcium and total alkalinity budgets and calcium carbonate precipitation of a small hard-water lake. Arch. Hydrobiol. $73: 14-30$.

Parrish, F.K. 1968. Key to water quality indicator organisms of the southeastern United States. U.S. Dept. of Interior. FWPCA. U.S. GPO.

Penfound, W.T. 1956. Primary production of vascular water plants. Iimnol. Oceanogr. 1:92-102.

Pennak, R.W. 1953. Fresh-water invertebrates of the United States. Ronald Press Co.

Petre, T. 1968. Population changes in aquatic invertebrates living on two water plants in a tropical man-made lake. Hydrobiologia. 32:449-485.

Provost, M.W. 1958. Chironomids and lake nutrients in Florida. Sewage and Ind. Wastes. 30:1417-1419.

Ransom, J.D. and T.C. Dorris. 1972. Analysis of benthic community structure in a reservoir by use of diversity indices. Amer. Midland Nat. 87:434-447.

Raven, J.A. 1970. Exogenous inorganic carbon sources in plant photosynthesis. Biol. Rev. 45:167-221. 
Richards, F.A. and T.G. Thompson. 1952. The estimation and characterization of plankton population by pigment analysis. 2. A spectrophotometric method for the estimation of plankton pigments. J. Marine Res. $2: 156-172$.

Roback, S.S. 1974. Insects (Arthropoda: Insects), p. 313376. In C.W. Hart, Jr. and S.L.H. Fuller (eds.), Pollution ecology of freshwater invertebrates. Academic Press.

Rosine, W.N. 1955. The distribution of invertebrates on submerged aquatic plant surfaces in Muskee Lake, Colorado. Ecology. 36:308-314.

Shannon, E.E. and P.I. Brezonik. 1972. Limnological characteristics of north and central Florida lakes. Limnol. Oceanogr. 17:97-110.

Simpson, E.H. 1949. Measurement of diversity. Nature. $163: 688$.

Stangeberg, M. 1968. Bacteriostatic effects of some algae and Limna minor extracts. Hydrobiologia. $32: 88-96$.

Steward, K.K. 1970. Nutrient removal potentials of various aquatic plants. Hyacinth Contr. J. $8: 34-35$.

Steward, K.K. and R.A. Elliston. 1974. Growth of hydrilla in solution cultures at various nutrient levels. Fla. Scientist. 36:228-233.

U.S. Environmental Protection Agency. 1974. Methods for chemical analysis of water and wastes. National Environmental Research Center Analytical Quality Control Laboratory. Cincinnati, Ohio. U.S. GPO.

Usinger, R.I. 1968. Aquatic insects of California. University of California Press.

Wetzel, R.G. 1975. Iimnology. W.B. Saunders Co. Wilhm, J.I. and T.C. Dorris. 1968. Biological parameters for water quality criteria. Bio. Sci. 18:477-481.

Wilhm, J.I. 1970. Range of diversity index in benthic macroinvertebrate populations. J. Water Pollution Contr. Fed. 42:221-224. 